OAK RIDGE

NATIONAL

LABORATORY

MARTIN MALIETTA
Active Sites Environmental Monitoring Program: FY 1991 Report

\author{
T. L. Ashwood \\ D. S. Hicks \\ C. M. Morrissey
}

Environmental Sciences Division

Publication No. 3798
MANAGED BY

MARTIN MARIETTA ENERGY SYSTEMS, INC.

FOR THE UNITED STATES

DEPARTMENT OF ENERGY 
This report has been reproduced directly from the best available copy.

Available to DOE and DOE contractors from the Office of Scientific and Technical Information, P.O. Box 62, Oak Ridge, TN 37831; prices available from (615) 576-8401, FTS 626-8401.

Available to the public from the National Technical Information Service, U.S. Department of Commerce, 5285 Port Royal Rd., Springfield, VA 22161.

This report was prepared as an account of work sponsored by an agency of the United States Government. Neither the United States Government nor any agency thereof, nor any of their employees, makes any warranty, express or implied, or assumes any legal liability or responsibility for the accuracy, completeness, or usefulness of any information, apparatus, product, or process disclosed, or represents that its use would not intringe privately owned rights. Reference herein to any specific commercial product, process, or service by trade name, trademark, manufacturer, or otherwise, does not necessarily constitute or imply its endorsement, recommendation, or tavoring by the United States Government or any agency thereof. The views and opinions of authors expressed herein do not necessarily state or reflect those of the United States Government or any agency thereot. 
Environmental Sciences Division

\title{
ACTIVE SITES ENVIRONMENTAL MONITORING PROGRAM: FY 1991 REPORT
}

\author{
T. L. Ashwood, D. S. Hicks, and C. M. Morrissey
}

Environmental Sciences Division

Publication No. 3798

\section{Manuscript Completed: October 1991}

Date Published: November 1992

\author{
Prepared for \\ Office of Environmental Restoration and Waste Management \\ (EW 301035 0)
}

Prepared by the

OAK RIDGE NATIONAL LABORATORY

Oak Ridge, Tennessee 37831

managed by

MARTIN MARIETTA ENERGY SYSTEMS, INC.

for the

U.S. DEPARTMENT OF ENERGY under contract DE-AC05-84OR21400 


\section{CONTENTS}

Page

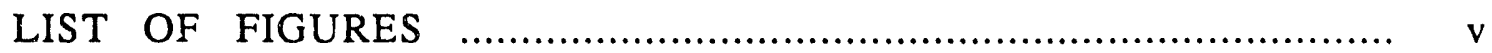

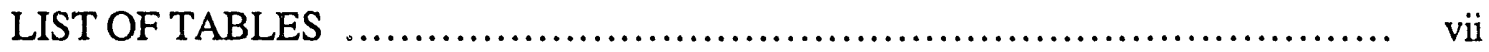

ABBREVIATIONS AND ACRONYMS …................................. ix

EXECUTIVE SUMMARY ….................................................... xi

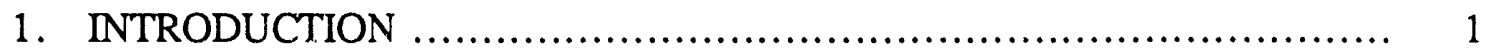

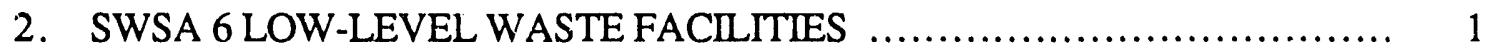

2.1 TUMULUS FACILITIES ……....................................... 2

2.1.1 Pad Runoff .................................................... 2

2.1.1.1 Methodology ............................................ 2

2.1.1.2 Tumulus I Results ........................................... 3

2.1.1.3 Tumulus II Results ......................................... 3

2.1.2 Groundwater Monitoring ........................................... 4

2.1.2.1 Methodology ............................................. 4

2.1.2.2 Results ................................................. 4

2.1.3 Conclusions and Recommendations ............................ 5

2.2 LLW SILOS, HIGH-RANGE WELLS, FISSILE WELLS, AND

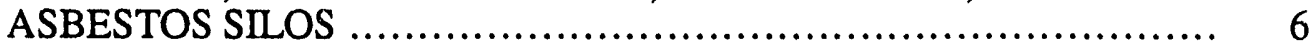

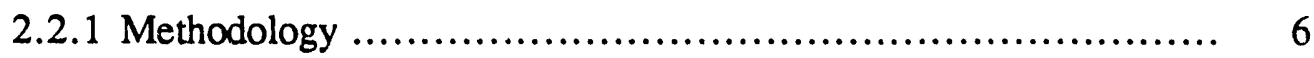

2.2.2 Results and Discussion ...................................... 6

2.2.2.1 Intratrench Wells .................................... 6

2.2.2.2 Wells Next to High-Range Wells, Fissile Wells, and Asbestos Silos 7

2.2.3 Recommendations ............................................. 8

2.3 GIILLCUT DISPOSAL TEST FACILITY .............................. 8

3. TRANSURANIC WASTE FACILITIES IN SWSA 5 NORTH .................... 9

3.1 METHODOLOGY ......................................................... 9

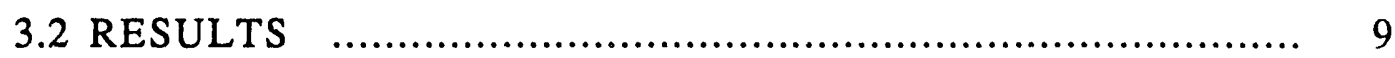

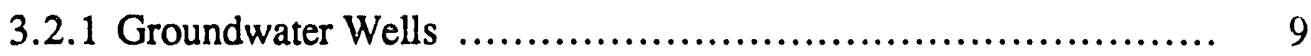

3.2.2 Seeps and Surface Water Samples ............................. 10

4. ACKNOWLEDGMENTS ................................................... 10

5. REFERENCES ............................................................. 10

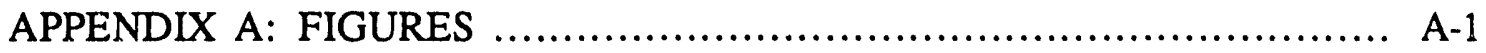

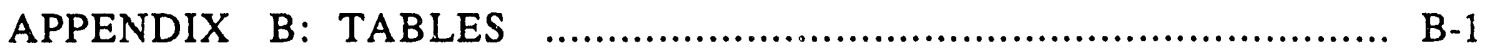




\section{LIST OF FIGURES}

Figure

$\underline{\text { Page }}$

A.1 Active low-level waste disposal sites in Solid Waste Storage Area 6, including the Tumulus I and II pads, the Interim Waste Management Facility (IWMF), the Hillcut Disposal Test Facility (HDTF), low-activity and high-activity silos, asbestos silos, fissile wells, high range wells, and capped areas

A.2 Transuranic waste storage sites, sampling locations, and major facilities in Solid Waste Storage Area 5 North

A.3 Tumulus area in Solid Waste Storage Area 6

A -4

A.4 Tritium concentrations in wells 1036 and 1039 


\section{LIST OF TABLES}

Table

B.1 Field parameters and radionuclide concentrations in samples from tumulus pads in SWSA 6

B.2 Field parameters and radionuclide concentrations in tumulus area monitoring wells

B.3 Radionuclide concentrations in samples from intratrench wells near low-level waste silos in SWSA 6 (May 1991)

B.4 Radionuclide concentrations in samples from monitoring wells near high range wells, asbestos silos, and fissile wells in SWSA 6 (May 1991)

B.5 Radionuclide concentrations in samples from intratrench wells near low-level waste silos in SWSA 6 (September 1991)

B.6 Radionuclide concentrations in samples from wells near high-range wells, asbestos silos, fissile wells in SWSA 6 (September 1991)

B.7 Radionuclide concentrations in samples from tank 1 at the Hillcut Disposal Test Facility in SWSA 6

B.8 Radionuclide concentrations in samples from SWSA 5 North 


\section{ABBREVIATIONS AND ACRONYMS}

$\mathrm{ACD}$ Analytical Chemistry Division

ASEMP

Active Sites Environmental Monitoring Program

DOE

U.S. Department of Energy

ESD

Envirunmental Sciences Division

HDTF

Hillcut Disposal Test Facility

IT

intratrench

LLW

low-level waste

MDA

minimum detectable activity

NPDES National Pollutant Discharge Elimination System

ORNL Oak Ridge National Laboratory

PWTP Process Waste Treatment Plant

QA quality assurance

RCRA Resource Conservation and Recovery Act

SWO Solid Waste Operations

SWSA solid waste storage area

TOC total organic carbon

TRU transuranic

WOC White Oak Creek 


\section{EXECUTIVE SUMMARY}

This report summarizes the activities of the Active Sites Environmental Monitoring Program (ASEMP) from April 1991 through September 1991. The ASEMP was established in 1989 by Solid Waste Operations (SWO) and the Environmental Sciences Division, both of Oak Ridge National Laboratory, to provide early detection and performance monitoring at active low-level (radioactive) waste (LLW) disposal sites in Solid Waste Storage Area (SWSA) 6 and transuranic (TRU) waste storage sites in SWSA 5 as required by chapters II and III of U.S. Department of Energy Order 5820.2A.

A new set of action levels was developed on the basis of a statistical analysis of background contamination. These new action levels have been used to evaluate results in this report.

Results of ASEMP monitoring continue to demonstrate that no LLW (except ${ }^{3} \mathrm{H}$ ) is being leached from the storage vaults on the tumulus pads. Loading of vaults on Tumulus II, which began in early FY 1991, was $>90 \%$ complete at the end of September 1991.

Beginning in June 1991, SWO personnel closed the drain lines from both tumulus pads and began trucking water from the pads to the Process Waste Treatment Plant (PWTP). Samples are obtained from accumulated water on each pad prior to transfer of the water to the PWTP.

Tumulus I was covered by a sheet of plastic throughout the period of this report; however, the cover leaks, and as much as $2000 \mathrm{gal}$ of water can accumulate on the pad during a prolonged rain event. This accumulated water has a $\mathrm{pH}$ of 9.4-10.6 and contains gross beta concentrations that exceed the $5.0 \mathrm{~Bq} / \mathrm{L}$ ASEMP action level (up to $54 \mathrm{~Bq} / \mathrm{L}$ ). The gross beta activity is derived from ${ }^{40} \mathrm{~K}$. Specific conductance ranged from 1440 to $5740 \mu \mathrm{S} / \mathrm{cm}$. These parameters ( $\mathrm{pH}$, gross beta $40 \mathrm{~K}$, and specific conductance) suggest that leaching of the concrete is occurring.

The $\mathrm{pH}$ of water on the Tumulus II pad increased to $>9.0$ from late May through early August and then declined below 9.0 beginning in laie August. Gross beta concentrations in samples of water from the Tumulus II pad have exceeded the action level on three occasions.

Tritium concentrations in water from Tumulus II reached as high as $67,000 \mathrm{~Bq} / \mathrm{L}$, while ${ }^{3} \mathrm{H}$ concentrations in the Tumulus II underpad drain increased to $12,000 \mathrm{~Bq} / \mathrm{L}$, and the ${ }^{3} \mathrm{H}$ concentration in well 1259 (south of Tumulus II) rose to $570 \mathrm{~Bq} / \mathrm{L}$. The source of ${ }^{3} \mathrm{H}$ was determined to be a single vault, and this vault was moved to an area of the pad where it was not in contact with standing water. Tritium concentrations in the pad water, underpad drain, and well 1259 have declined to prior levels after movement of the vault. This episode suggests a hydraulic connection between the pad, the underpad, and the underlying groundwater.

Groundwater monitoring data from the tumulus wells continue to show the plume of ${ }^{3} \mathrm{H}$ believed to originate from the discharge of the 49-Trench area French drain. This problem was reported in FY 1990, and corrective actions were taken then. The plume may be expanding to include the well south of Tumulus I.

Four intratrench (IT) wells around LLW silos contained elevated levels of gross alpha and/or gross beta contamination in the May 1991 samples. However, all gross alpha and 
gross beta concentrations were below action levels in the September samples, except for wells 27 and 31 . Changes in sample preparation procedures have been made to improve the sensitivity of gross alpha and gross beta measurements. In the September 1991 samples, three IT wells contained gamma emitting radioisotopes above the action levels. Wells that continue to contain elevated concentrations of alpha, beta, and gamma emitting isotopes will be investigated further to determine the causes.

Well 516, just downslope from the SWSA 5 North trenches, continues to show levels of ${ }^{244} \mathrm{Cm}$ and ${ }^{241} \mathrm{Am}$ substantially above background. In addition, wells 521 and 716 contained detectable concentrations of ${ }^{244} \mathrm{Cm}$. 


\section{INTRODUCTION}

Chapter III of U.S. Department of Energy (DOE) Order 5820.2A (DOE 1988) sets forth requirements for management of the facilities in Solid Waste Storage Area (SWSA) 6 (Fig. A.1) that were used for disposal of solid low-level (radioactive) waste (LLW) on or after the date of the order (September 26,1988). The transuranic (TRU) waste storage areas in SWSA 5 North (Fig. A.2) are covered by Chapter II of the order. Both chapters require environmental monitoring to provide early warning of leaks before those leaks pose a threat to human health or the environment. Chapter III also requires that monitoring be conducted to evaluate the performance of LLW disposal facilities. In accordance with this order, the Solid Waste Operations (SWO) Department at Oak Ridge National Laboratory (ORNL) has established an Active Sites Environmental Monitoring Program (ASEMP) that is implemented by staff of the Environmental Sciences Division (ESD) at ORNL.

This report presents data from ASEMP activities for the second half of FY 1991. The monitoring methodology is described in the ASEMP program plan (Ashwood et al. 1990a). However, a summary of the methodology for each major area is presented in this report together with any changes that occurred during the report period.

During this reporting period, a statistical analysis of background contamination in SWSA 5 North and SWSA 6 was used to establish new action levels for ASEMP monitoring activities (Ashwood and Ashwood 1991). Results in this report are evaluated against these new action levels.

Throughout the report, several recommendations are presented. These recommendations coupled with those from previous reports will be incorporated into draft revisions of the ASEMP monitoring plan and quality assurance (QA) plan. The revised monitoring and QA plans will also incorporate monitoring activities related to the new Interim Waste Management Facility (IWMF) in SWSA 6 (Fig. A.1), which is scheduled to begin operation in early FY 1992. Monitoring activities associated with proposed new LLW and TRU facilities to be built east of the High Flux Isotope Reactor will be included in subsequent revisions of the plans.

\section{SWSA 6 LOW-LEVEL WASTE FACILITIES}

SWSA 6 is currently the only operating LLW disposal facility on the Oak Ridge Reservation. Solid wastes that have been certified free of liquids and hazardous substances are further segregated into low- and high-activity wastes prior to disposal. Low-activity wastes are disposed of in concrete silos installed in trenches or in concrete vaults on concrete pads above ground (called tumulus facilities) (Fig. A.1). High-activity wastes are disposed of in silos or in steel-lined, concrete-capped high-range wells, ${ }^{1}$ depending upon the waste form and activity (Fig. A.1). Asbestos waste that cannot be certified free of radioactive contamination is placed in concrete silos below ground. Fissile material is disposed of in steel-lined welis. During the mid-1980s, high-activity wastes were disposed of in concrete vaults (similar to tumulus vaults) placed on a concrete pad cut into the side of a hill as a demonstration of this method of disposal. This Hillcut Disposal Test Facility (HDTF) is not an active site, but it is included in the ASEMP.

\footnotetext{
${ }^{1}$ Preceding ASEMP reports refer to these wells as high-activity auger holes. The change is being made here to more accurately reflect the nature of the wells.
} 
Monitoring activities associated with the SWSA 6 facilities are divided into three major areas: tumulus, subsurface facilities, and HDTF. Tumulus monitoring activities include pad runoff monitoring as well as monitoring of water in the underpad area and in groundwater below the pads. Monitoring at the subsurface facilities includes sampling of the perched water table that develops when shallow storm flow intercepts the silo trenches or the backfill surrounding high-range wells, asbestos silos, and fissile wells. At the HDTF, water that accumulates on the pad or in the underpad area is collected and sampled.

\subsection{TUMULUS FACILITIES}

Monitoring procedures for sampling surface water runoff from both the Tumulus I and Tumulus II pads changed during this reporting period. Concerns over the release of water with relatively high $\mathrm{pH}$ and with some ${ }^{3} \mathrm{H}$ and gross beta activity to the West Tributary prompted SWO personnel to close the surface water drain lines from each pad (Fig. A.3) and to collect all accumulated water for transport to the Process Waste Treatment Plant (PWTP) after sampling. Thus, the majority of the samples collected during the past 6 months were taken by direct sampling water on the pads rather than through the flow proportional sampling device located in the tumulus monitoring shed.

Most of the equipment designed for continuous data collection such as the pressure transducers, rain gage, runoff flow measurement device, and meteorological instruments were taken off line and are being tested and recalibrated in anticipation of their reuse at the IWMF. Approximately 3 years of data were collected and archived prioir to this reporting period on groundwater elevation, pad runoff flow rate and total flow, wind speed and direction, rainfall, relative humidity, solar radiation, and temperature (see C. M. Morrissey, ORNL, for archived data).

Three rounds of quarterly sampling of the 12 tumulus area groundwater monitoring wells (Fig. A.3) were completed, and the analytical data are reported herein. The dedicated sampling pumps in each well will remain in place, and the wells will continue to be sampled on a regular basis after both tumulus pads are fully loaded and the focus of monitoring efforts shifts to the IWMF.

\subsubsection{Pad Runoff}

\subsubsection{Methodology}

The first samples from this period (Table B.1: TMOI-412 and TMOII-CS-072) were collected by allowing Tumulus II runoff to continuously flow through the monitoring shed flume; the Tumulus I drain lines were initially closed and then opened once Tumulus II stopped draining. The flow proportional sampler collected $1 \mathrm{~L}$ of sample from every 1000 $L$ of runoff. In mid-April the surface drain lines from both pads were left open continuously, thus allowing both pads to drain to the monitoring shed. Samples TMOII-CS-060 through TMOII-CS-068 represent composite samples of the combined runoff from both pads. The majority of this combined flow is from Tumulus II because Tumulus I has a temporary cover in place. In mid-May the Tumulus I surface drain lines were again closed, and samples were thereafter always collected directly from water standing on the surface of this pad. TMOII-CS-070 through TMOII-CS-078 are, thus, composite samples of Tumulus II runoff only. When the $\mathrm{pH}$ of Tumulus II runoff water appeared to be stabilizing around 9.5 in late May and early June, SWO personnel decided 
to close the surface drain lines from Tumulus II and to pump the accumulated water off the pad for transport to the PWTP. Samp? TMOII-080 and all subsequent Tumulus II samples were collected directly from the pad.

\subsubsection{Tumulus I Results}

The $\mathrm{pH}$ of the Tumulus I surface water has consistently remained in the 9.5 to 10.5 range; there was one recent (TMOI-448) anomalously low value of 8.62 ; however (Table B.1). Specific conductance values are between 1500 and $5800 \mu \mathrm{S} / \mathrm{cm}$ and generally rise during mid- to late summer, perhaps because of increased algal growth on the covered pad
(Table B.1).

Gross beta concentrations in the surface samples are well above the action level of $5 \mathrm{~Bq} / \mathrm{L}$, with the exception of a low value in the same sample (TMOI-448) that had the low $\mathrm{pH}$ (Table B.1). All but three samples contained measurable activities of $40 \mathrm{~K}$, which is apparently the source of the elevated gross beta activity (Table B.1). Previous reports (Wickliff et al. 1991a,b; Ashwood et al. 1991) have speculated that potassium is leaching from the concrete and/or coming from soil present on the pad. The one underpad sample (TMOI-426UND) that was analyzed for gross radionuclide parameters contained gross beta below the action level (Table B.1).

In response to an increase in ${ }^{3} \mathrm{H}$ activity in monitoring well 1259 observed in the April 1991 quarterly sampling (Table B.2), samples were taken of the surface water from both pads and from the underpad drains for ${ }^{3} \mathrm{H}$ analysis. Results indicate an as yet unexplained elevated ${ }^{3} \mathrm{H}$ activity in the Tumulus I surface water samples that is consistently between 1000 and $3000 \mathrm{~Bq} / \mathrm{L}$ (Table B.1). Tumulus I underpad drain samples showed no ${ }^{3} \mathrm{H}$ activity above expected background levels (Table B.1). Samples taken since 20 August 1991 consistently show higher counting errors than previous samples (Table B.1). As a result of the higher counting errors, three samples (Table B.1) equalled or exceeded the ${ }^{60} \mathrm{Co}$ action level (1.5 Bq/L: Ashwood and Ashwood 1991), although none of these samples were significantly greater than zero $(p>0.05)$. One sample (Table B.1) exceeded the ${ }^{137} \mathrm{Cs}$ action level (2.5 Bq/L: Ashwood and Ashwood 1991), and this sample was significantly greater than zero $(\mathrm{p}<0.05)$.

Data for the remaining parameter commonly measured in the pad surface-water samples, total organic carbon (TOC), are incomplete. The data that have been received are variable and similar to previously reported data. The variability in the data is probably a result of algal growth on the pad, which may be present in the samples to a greater or lesser degree, depending upon the sampling time and location.

\subsubsection{Tumulus II Results}

The $\mathrm{pH}$ of Tumulus II surface water is variable (Table B.1) and often above the National Pollutant Discharge Elimination System (NPDES) permit level of 9.0 at the West Tributary outfall. This exceedance of the established NPDES permit $\mathrm{pH}$ was the primary motivation for SWO personnel to stop discharge to the tributary and to collect the surface water for transport to the PWTP. Since release of the pad water was stopped, $\mathrm{pH}$ values have been variable and often below 9.0 (Table B.1). Specific conductance values of the pad surface water are in the range of 100 to $625 \mu \mathrm{S} / \mathrm{cm}$ (Table B.1) and are consistent with 
previously observed values for the uncovered pad (Ashwood et al. 1991). TOC data are incomplete and vary widely from 2 to $53 \mathrm{mg} / \mathrm{L}$.

The gross beta action level of $5 \mathrm{~Bq} / \mathrm{L}$ was exceeded on only three occasions, and only one of the exceedances (TMOII-CS-060) occurred during a period of release to the tributary (Table B.1). The one release that exceeded the action level was actually a combined release of water from both pads. Several surface-water and underpad-drain-water samples contained gross alpha concentrations greater than zero, but none of the samples were above the $1 \mathrm{~Bq} / \mathrm{L}$ action level (Table B.1). One sample (TMOII-104) had an elevated ${ }^{60} \mathrm{Co}$ level of $3.3 \mathrm{~Bq} / \mathrm{L}$. The blank (deionized water) (TMOII-105) submitted with this sample was reported to contain $2.6 \pm 2.6 \mathrm{~Bq} / \mathrm{L}$ of $60 \mathrm{Co}$, which is not significantly different from the sample value ( $p>0.05$ ). Nevertheless, an archive of this sample has been resubmitted for analysis.

Tritium measurements began in late May and revealed substantially elevated concentrations in hoth the pad surface water and the underpad drain water (Table B.1). SWO personnel investigated the possible source of this ${ }^{3} \mathrm{H}$ and discovered one vault into which a substantial amount of ${ }^{3} \mathrm{H}$ had been placed. This vault was relocated in mid July to the upper end of the pad, where it would no longer be in continuous direct contact with water accumulating on the pad. Subsequent ${ }^{3} \mathrm{H}$ data for surface-water samples show much lower concentrations, similar to those observed on Tumulus I (Table B.1). No underpad-drain-water sample has been collected since the ${ }^{3} \mathrm{H}$-containing vault was moved.

\subsubsection{Groundwater Monitoring}

\subsubsection{Methodology}

The Tumulus pads are encircled by 12 monitoring wells (Fig. A.3) that were drilled to auger refusal and are finished in zones of permanent groundwater (Wickliff et al. 1991b: Appendix C). Exact construction details of well 381 are uncertain because this well was drilled prior to the start of tumulus activities. Each well (excluding 381) contains a dedicated bladder pump and is sampled on a quarterly basis for radiological and field parameters (e.g., pH and specific conductance). Field parameters are measured using a Hydrolab Model II sample analyzer equipped with a flow-through cell. Samples are collected on an annual basis from six randomly selected wells, and these samples are analyzed for cations, anions, TOC, and volatile and semivolatile organics.

\subsubsection{Results}

Analytical results from three rounds of quarterly groundwater sampling are presented in Table B.2. The field parameters, $\mathrm{pH}$, and specific conductance are very consistent from one sampling period to the next and are within the range of values previously observed for the tumulus area (Wickliff et al. 1991a,b; Ashwood et al. 1991).

Some groundwater samples had gross alpha and gross beta concentrations greater than zero, but none approached either action levels of 1 and $5 \mathrm{~Bq} / \mathrm{L}$, respectively. All ${ }^{60} \mathrm{Co}$ or ${ }^{137} \mathrm{Cs}$ concentrations were well below action levels. The ${ }^{3} \mathrm{H}$ concentrations in well 1036 and 1039 continue to increase (Table B.2 and Fig. A.4). Tritium in well 1037 increased from $64 \pm 22 \mathrm{~Bq} / \mathrm{L}$ in April 1991 to $410 \pm 40$ in July 1991 (Table B.2). 


\subsubsection{Conclusions and Recommendations}

The method of disposing of tumulus pad water by pumping and treating eliminates the concern about directly releasing such water to the environment. However, from a performance standpoint, questions remain about what the high $\mathrm{pH}$ values, elevated gross beta $/ 40 \mathrm{~K}$ concentrations, and ${ }^{3} \mathrm{H}$ escape from the vaults mean in regard to the long-term integrity of the tumulus. Despite these questions, the data presented in this report show that the tumulus vaults continue to contain the LLW emplaced within them (except for ${ }^{3} \mathrm{H}$ ).

Both pads will soon be covered by a tent-like structure that should provide more adequate protection from rainwater infiltration than did the temporary cover over Tumulus I. We recommend observation of both pads for water intrusion and continued sampling and analysis of any water that may accumulate. Also, water from the underpad drains should be sampled on a regular basis because this is water from the tumulus area that will still be discharged through the monitoring shed to the tributary at the NPDES outfall.

Elevated ${ }^{3} \mathrm{H}$ activities have been observed for some time in wells 1036 and 1039 (Wickliff et al. 1991a,b; Ashwood et al. 1991), and the source of this ${ }^{3} \mathrm{H}$ is believed to be the outfall of the French drain located east of the pad (Davis et al. 1985). The ${ }^{3} \mathrm{H}$ plume is presumed to move most rapidly along geologic strike from well 1036 to well 1039. Corrective measures were taken in January 1990 to extend the French drain outfall to a nearby surface drainage, thereby eliminating seepage into the groundwater (Wickliff et al. 1991a). This action has not yet had any effect on the tumulus wells, and visual inspection of the drain extension suggests that water leakage from the plastic line may be compromising the effectiveness of the corrective action. The most recent data show steadily increasing concentrations of ${ }^{3} \mathrm{H}$ in well 1036. The increase in the ${ }^{3} \mathrm{H}$ concentration in well 1037 (Table B.2 and Fig. A.4) may indicate some spreading of the plume. We strongly recommend that the plastic hose used to extend the French drain outfall be carefully inspected by SWO personnel on a regular basis and action be taken immediately to stop any leaks that may be found.

Tritium activity in well 1259 (Fig. A.3: located between the pads and immediately adjacent to pad II) decreased substantially from $570 \mathrm{~Bq} / \mathrm{L}$ in April 1991 to $100 \mathrm{~Bq} / \mathrm{L}$ in July 1991. The eason for this decrease is unclear, but there may be some relationship between ${ }^{3} \mathrm{H}$ concentrations in 1259 and in the Tumulus II underpad area. Furthermore, ${ }^{3} \mathrm{H}$ concentrations in well 1256 (Fig. A.3: north of Tumulus II) have increased to $410 \mathrm{~Bq} / \mathrm{L}$ in July 1991. The cause of this increase is also unknown. Further investigation of the hydrologic connections between the monitoring wells and the Tumulus II underpad area is needed.

The presence of ${ }^{3} \mathrm{H}$ in the Tumulus II underpad area concurrent with elevated concentrations in the water standing on the pad suggests that there is a hydraulic connection between the pad and underpad area. Such a connection represents a breach of the containment provided by the pad and should be investigated.

Becuase there is a continued presence of ${ }^{3} \mathrm{H}$ in the Tumulus groundwater monitoring wells, quarterly groundwater sampling should continue after the pads are covered. Further investigation into the source of the ${ }^{3} \mathrm{H}$ may be warranted if activity continues to spread to other wells in the area or if activity continues to be observed in the underpad drains. Also, manual water level monitoring in the tumulus wells should continue. 


\subsection{LLW SILOS, HIGH-RANGE WELLS, FISSILE WELLS, AND ASBESTOS SILOS}

\subsubsection{Methodology}

LLW silos in SWSA 6 are generally installed in groups of four within a trench. The condition of the disturbed soil (backfill) in trenches can cause an intermittent perched water table as a result of subsurface stormflow. Davis et al. (1989) demonstrated that some of the LLW silos within trenches leak. Therefore, in order to provide early contaminant detection within each trench, 2 -in. drivepoint monitoring wells with 5-ft screened sections were installed in May 199 n in trenches that previously were without monitoring wells. Each intratrench (IT) well is equipped with a weighted sample bottle (monitored quarterly) that collects a sample of any perched water. These wells provide a way to monitor groups of silos for containment failure, leaching of wastes, and contaminant transport.

Drivepoint wells were also installed in the backfilled soil next to high-activity high-range wells, fissile wells, and asbestos silos. These wells are also equipped with weighted sample bottles and monitored quarterly.

Until the last (fourth) quarterly sampling, samples were prepared for analyses by acidifying the sample (to $\mathrm{pH}<2$ ) with nitric acid before filtration (through 0.45 - $\mu \mathrm{m}$ filters) so that all contamination was detected, whether it was part of the dissolved load or associated with suspended sediment. However, this method appears to cause an increase in dissolved solids, which lowers the counting efficiency of the gross alpha and gross beta analyses (J. W. Wade, ORNL Analytical Chemistry Division, personal communication, to D. S. Wickliff, ORNL Environmental Sciences Division, 1991). During the gross analyses, more solids remaining behind on the planchette after evaporation cause greater absorption of alpha and beta particles, which in turn results in lower counting efficiency. Therefore, to reduce the amount of dissolved solids, samples from the fourth quarterly sampling were filtered prior to acidification. Filters from the fourth quarter were counted for gamma emitting isotopes in ESD. Filters from the third quarter were not counted. The quarterly water samples are analyzed for gamma emitting isotopes by ESD and ACD and for gross alpha and gross beta activities by ACD.

\subsubsection{Results and Discussion}

The third and fourth FY 1991 quarterly samplings of IT wells around LLW silos and of wells next to asbestos silos, high-range wells, and fissile wells were completed in May and September, respectively. Samples were collected from most of the 44 intratrench wells around LLW silos, from both wells next to the two asbestos silos, and from both wells next to the two fissile wells (Tables B.3-B.6). Samples were also collected from eight of the nine wells in the high-range wells area during the third quarter and from five of these wells during the fourth quarter (Tables B.4 and B.6).

\subsubsection{Intratrench Wells}

Samples from four IT wells had gross alpha or gross beta concentrations that exceeded the SWSA 6 action levels of $1 \mathrm{~Bq} / \mathrm{L}$ and $5 \mathrm{~Bq} / \mathrm{L}$ (Ashwood and Ashwood 1991), respectively, during the third quarter (Table B.3). High counting error suggests that the gross beta concentration in well 22 is not significantly greater than zero $(p>0.05)$. All other results are statistically significant $(p<0.05)$. 
Biank samples and duplicate samples were not submitted with the third-quarter samples, so we cannot determine whether the high gross alpha concentrations in wells 22 , 35 , and 43 resulted from analytical lab problems, as has been seen in prior ASEMP results (Wickliff et al. 1991b). All previous samiples from these wells have contained gross alpha and gross beta concentrations below the action levels (Wickliff et al. 1991a,b; Ashwood et al. 1991). During the fourth quarter, gross alpha and gross beta concentrations in three of these four IT wells returned to background levels (Table B.5).

Samples from two wells had gross alpha concentrations that exceeded the action level during the fourth quarter. Well 27 contained $2.5 \pm 1.8 \mathrm{~Bq} / \mathrm{L}$ gross alpha and well 31 contained 1.8 $\pm 1.1 \mathrm{~Bq} / \mathrm{L}$ gross alpha (Table B.5).

Although no sample was collected from well 19 during the fourth quarter because the well was dry, previous samples from well 19 have consistently contained elevated gross beta concentrations, primarily resulting from elevated ${ }^{90} \mathrm{Sr}$ activity (Wickliff et al. $1991 \mathrm{~b}$, Ashwood et al. 1991). The elevated activity suggests one of three possible contaminant pathways: (1) one or more of the silos (Nos. 498-501) within the trench have containment fail te that allows water to enter the waste and to leach contaminants, (2) shallow stormflow entering the trench has been contaminated by soil in the area, or (3) contaminated groundwater below the trench occasionally enters the trench. The silos within the trench were installed using precast concrete drainage pipes obtained from the Clinch River Breeder Reactor Project, and the wastes within the silos were not grouted. These silos will be filled with grout as part of a program to fill all ungrouted silos prior to closure of SWSA 6.

Fourth-quarter samples from wells $12,17,31,32$, and 35 (Table B.5) exceeded the $60 \mathrm{Co}$ action level (1.5 Bq/L: Ashwood and Ashwood 1991). However, based on counting errors, ${ }^{60} \mathrm{Co}$ concentrations in wells 17 and 32 were not significantly greater than zero $(p>$ 0.05 ). Concentrations of gamma emitting isotopes on the filters from the fourth-quarter IT well samples were below minimal detectable activity (MDA) (typically $<0.1 \mathrm{~Bq}$ ), with the exception of some ${ }^{137} \mathrm{Cs}$ (equivalent to $0.62 \pm 0.08 \mathrm{~Bq} / \mathrm{L}$ of water) found on the filter from well 26. Plans for further investigation will be developed if samples from these wells continue to contain elevated activities.

\subsubsection{Wells Next to High-Range Wells, Fissile Wells, and Asbestos Silos}

Gross alpha concentrations were below the action level in wells next to high-range wells, fissile wells, and asbestos silos, with the exception of a gross alpha concentration of $1.3 \pm 0.4 \mathrm{~Bq} / \mathrm{L}$ in the well next to asbestos silo C595 during the third quarter (Table B.4). During the previous quarter the C595 sample had a gross alpha concentration of $1.4 \pm 0.7$ $\mathrm{Bq} / \mathrm{L}$ (Ashwood et al. 1991: Table B.5); however, the gross alpha concentration was well below the action level during the fourth quarter (Table B.6).

Gross beta concentrations were below the action level in wells next to high-range wells, fissile wells, and asbestos silos, with the exception of a gross beta concentration of $24 \pm 1 \mathrm{~Bq} / \mathrm{L}$ in well AUG 48 during the third quarter (Table B.4). This gross beta concentration was probably associated with the elevated ${ }^{137} \mathrm{Cs}$ concentration $(29 \pm 3 \mathrm{~Bq} / \mathrm{L})$ also detected in that sample. During the fourth quarter both gross beta and ${ }^{137} \mathrm{Cs}$ concentrations in well AUG 48 were below action levels (Table B.6); however, the filter had a ${ }^{137} \mathrm{Cs}$ concentration equivalent to $5.93 \pm 1.2 \mathrm{~Bq} / \mathrm{L}$ of water. If the first quarter 
FY 1992 sample from well AUG 48 contains elevated gross beta and ${ }^{137} \mathrm{Cs}$ concentrations, plans for further investigation of the contamination will be developed.

During the fourth quarter three wells adjacent to high-range wells and fissile wells (Table B.6) contained ${ }^{60} \mathrm{Co}$ concentrations above the new action level of $1.5 \mathrm{~Bq} / \mathrm{L}$ (Ashwood and Ashwood 1991). However, only in well AUG 50 was the ${ }^{60} \mathrm{Co}$ concentration significantly greater than zero $(p<0.05)$. In addition, ${ }^{60} \mathrm{Co}$ activities on the filters were below MDAs (typically $<0.1 \mathrm{~Bq}$ ).

\subsubsection{Recommendations}

Blank samples will be submitted with each batch of samples. This procedure is already followed on tumulus area samples and will be ini:o porated into all aspects of the ASEMP sampling. Duplicates will be submitted for $10 \%$ of the samples in each batch whenever possible; however, the small quantity of water usually available in each IT well minimizes the number of duplicate samples possible.

Acidification of samples prior to filtration creates problems in subsequent analyses. However, it is important to understand the total contamination present in the $I T$ wells, and it appears that counting filters for gamma emitting radionuclides may allow for greater sensitivity than counting the water samples using the previous method because the MDA for water samples was typically $\sim 2.5 \mathrm{~Bq} / \mathrm{L}$. Therefore, we will continue to gamma count the filters from each sample to ensure that excessive contamination associated with particulate material is not missed.

\subsection{HILLCUT DISPOSAL TEST FACILITY}

Runoff from the pad is designed to collect in an above-grade tank (tank No.1) at the Hillcut Dispissal Test Facility (HDTF). Volume measurements of pad runoff were made weekly through September 1991. These measurements indicate that pad runoff remained minimal, and samples were collected from tank No.1 on only two occasions when the tank was found to be near its maximum capacity. After a sample is collected, the contents of tank No.1 are transferred to a holding tank until radionuclide results are received. Samples are submitted to ACD for gamma, gross alpha, and gross beta analyses. During the period of monitoring, April 1991 through September 1991, radionuclide concentrations in samples collected from tank No.1 were below action levels (Table B.7).

Runoff from the underpad gravel drain is also designed to collect in an above-grade tank (tank No.2). However, a leak in the bottom of tank No.2 was found in February, so the water was rerouted to a holding tank downslope from HDTF. There was no groundwater runoff, and the holding tank remained dry during the monitoring period.

Two wells at HDTF were monitored weekly during the period. The well in the gravel layer around the pad remained dry, except for the first week of April following a large rainstorm ( 2.5 in.) in late March. Weekly water levels in the well on the pad remained fairly constant. Water levels indicate that a small amount of standing water (depth $\leq 0.5$ in.) remains on the pad. 


\section{TRANSURANIC WASTE FACILITIES IN SWSA 5 NORTH}

As part of the ASEMP, streams and groundwater wells around the TRU waste storage area in SWSA 5 North are sampled quarterly (Ashwood et al. 1990a). Well 516, immediately downgradient from a group of TRU waste trenches (Fig. A.2), con! ains gross alpha activity varying from 30-150 Bq/L (Ashwood et al. 1990b; Wickliff et al. 1991a,b; Ashwood et al. 1991). Curium-244 is the dominant radionuclide, and traces of $241,243 \mathrm{Am}$ have been reported from separate samples. The TRU waste trenches also contain some Resource Conservation and Recovery Act (RCRA)-regulated wastes-primarily elemental lead (Stewart et al. 1989). Samples from well 516 have not contained detectable concentrations of volatile organics (Wickliff et al. 1991b). Metal concentrations have been below regulatory concern (Ashwood et al. 1991). The trenches are upgradient from White Oak Creek (WOC), which drains most of ORNL and eventually enters the Clinch River. Curium-244 and ${ }^{241}$ Am were measured in two seeps (Fig. A.2: WOC 213 and WOC 255) in the bank of WOC (Ashwood et al. 1991). These seeps are along geologic strike with the trenches.

\subsection{METHODOLOGY}

In addition to the routine quarterly samples from wells, seeps, and streams (Ashwood et al. 1990a), water samples were collected from wells 708, 715, and 716 and from several seeps in the bank of WOC (Fig. A.2). Well samples were taken after one to three well volumes had been evacuated from the well or after the well had been pumped dry and allowed to recover.

Gamma counting, gross alpha, and gross beta analyses were performed on 1-L samples. Separate $250-\mathrm{mL}$ samples were collected for ${ }^{3} \mathrm{H}$ analyses. All samples were filtered through separate 0.45 -micron filters and then acidified with nitric acid to $\mathrm{pH}<2$ ( ${ }^{3} \mathrm{H}$ samples were not acidified).

\subsection{RESULTS}

\subsubsection{Groundwater Wells}

Well 516 contained gross alpha concentrations well above the action level during both sampling periods (Table B.8) as in previous samples (Ashwood et al. 1990b; Wickliff et al. 1991a,b; Ashwood et al. 1991). During both sample periods, well 516 also contained gross beta concentrations above the new action level for SWSA 5 North $(2 \mathrm{~Bq} / \mathrm{L}$ : Ashwood and Ashwood 1991). Potassium-40 was not detected in either sample, and the ${ }^{137} \mathrm{Cs}$ concentrations were not sufficient to accoun: for the gross beta activity (Table B.8). The next quarterly sample will be analyzed for ${ }^{90} \mathrm{Sr}$.

No other well samples contained gross alpha or gross beta concentrations above action levels. However, well 521 contained ${ }^{244} \mathrm{Cm}$ at a concentration that was significantly greater than zero $(\mathrm{p}<0.05)$ in August 1991 (Table B.8). Well 716 also contained a statistically significant $\left(p<0.05\right.$ ) concentration of ${ }^{244} \mathrm{Cm}$, but the concentration was an order of magnitude lower than that in well 521 (Table B.8). This is the first analysis for specific alpha emitting isotopes in wells other than 516, and therefore the first indication of possible TRU contamination outside of well 516 and the WOC bank seeps. If these wells 
contain ${ }^{244} \mathrm{Cm}$ during the next quarterly sampling, action plans for further investigation will be developed.

Gamma emitting isotopes were present in wells 51.9, 522, and 524 at concentrations above the new action levels $\left({ }^{60} \mathrm{Co}=1.5 \mathrm{~Bq} / \mathrm{L}\right.$ and ${ }^{137} \mathrm{Cs}=1.0 \mathrm{~Bq} / \mathrm{L}$ : Ashwood and Ashwood 1991) during the most recent sample period (Table B.8). However, only the ${ }^{137} \mathrm{Cs}$ concentration in well 522 and the ${ }^{60} \mathrm{Co}$ concentration in well 524 were significantly greater than zero $(p<0.05)$ when counting errors were considered. If the next quarterly sample round reveals concentrations above the action level in these wells, plans for further investigation will be developed.

\subsubsection{Seeps and Surface Water Samples}

Bank seeps at WOC 213 and WOC 255 contained statistically significant $(p<0.05)$ concentrations of ${ }^{244} \mathrm{Cm}$ in April 1991 (Table B.8), although only the WOC 213 seep exceeded the gross alpha action level. In addition, seep 5NW 02 contained measurable ${ }^{244} \mathrm{Cm}$ in April 1991, even though the gross alpha concentration was below the action level. This was the first time that the $5 \mathrm{NW}$ seeps had been analyzed for specific alpha emitting isotopes. The 5NW seeps and the seep at WOC 213 were dry during the September 1991 quarterly sampling.

Sediment filtered from one WOC 160 seep sample contained elevated ${ }^{60} \mathrm{Co}$ and ${ }^{137} \mathrm{Cs}$ concentrations (Table B.8). The sediment in this sample had the orange hue that is characteristic of ferric hydroxide precipitate. A second sample from WOC 160 that was relatively clear was also filtered, and this filter had no detectable gamma emitting isotopes (Table B.8). The filter from the WOC 255 seep sample contained ${ }^{137} \mathrm{Cs}$. Because it is difficult to separate the sediment originating within the seep from the sediment on the bank and because the sediment on the bank is known to contain substantial gamma emitting contamination (Ashwood et al. 1991), these results are equivocal at best. The filtered water from both seeps contained only background levels of radionuclides.

\section{ACKNOWLEDGMENTS}

The authors wish to thank Scott Gregory, Arnold Hunley, Lauren Larsen, Della Marshall, Lisa Schilling, Tony Thomas, and Jeff Wade for valuable assistance in the sampling and analysis of the data.

\section{REFERENCES}

Ashwood, J. S., and T. L. Ashwood. 1991. Active sites environmental monitoring program: Action levels. ORNL/M-1569. Oak Ridge National Laboratory.

Ashwood, T. L., D. S. Wickliff, and C. M. Morrissey. 1990a. Active Sites Environmental Monitoring Program: Program plan. ORNL/M-1197. Oak Ridge National Laboratory.

Ashwood, T. L., D. S. Wickliff, C. M. Morrissey, and H. L. Adair. 1990b. Active sites monitoring at Oak Ridge National Laboratory. pp. 397-399 In Proceedings of SPECTRUM 90 Nuclear and Hazardous Waste Management International Topical Meeting, September 30-October 4, 1990, Knoxville, Tennessee. American Nuclear Society, La Grange Park, Illinois. 
Ashwood, T. L., D. S. Wickliff, and C. M. Morrissey. 1991. Active Sites Environmental Monitoring Program: Mid-FY 1991 Report. ORNL/M-1442. Oak Ridge National Laboratory.

Davis, E. C., R. G. Stansfield, L. A. Melroy, and D. D. Huff. 1985. Water diversion at low-level waste disposal sites. J. Environ. Eng. 111(5):714-29.

Davis, E. C., C. W. Francis, and R. J. Luxmoore. 1989. An evaluation of water inleakage into concrete low-level radioactive waste disposal silos at ORNL's Solid Waste Storage Area six. ORNL/TM-11164. Oak Ridge National Laboratory.

Stewart, R. C., L. S. Dickerson, S. F. Joost, and D. C. Osucha. 1989. Remote-handled transuranic solid waste characterization study: Oak Ridge National Laboratory. ORNL/TM-11050. Oak Ridge National Laboratory.

U.S. Department of Energy (DOE). 1988. Radioactive waste management. DOE Order 5820.2A, September 26, 1988. Washington, D.C.

Wickliff, D. S., C. M. Morrissey, and T. L. Ashwood. 1991a. Active Sites Environmental Monitoring Program: Mid-FY 1990 summary report. ORNL/M-1179. Oak Ridge National Laboratory.

Wickliff, D. S., C. M. Morrissey, and T. L. Ashwood. 1991b. Active Sites Environmental Monitoring Program: FY 1990 annual report. ORNL/M-1327. Oak Ridge National Laboratory. 
APPENDIX A: FIGURES

A-1 


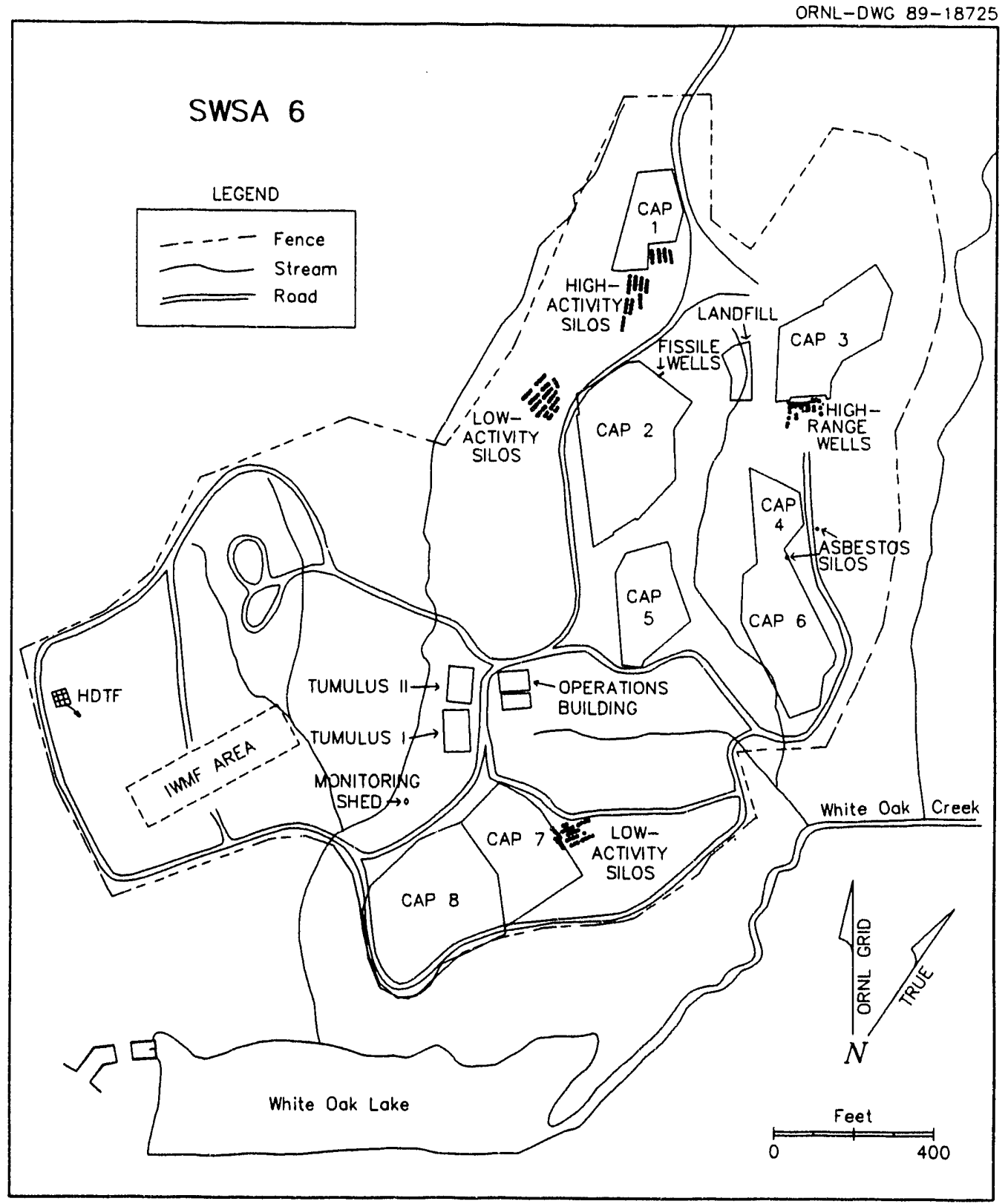

Fig. A.1. Active low-level waste disposal sites in Solid Waste Storage Area 6, including the Tumulus I and II pads, the Interim Waste Management Facility (IWMF), the Hillcut Disposal Test Facility (HDTF), low-activity and high-activity silos, asbestos silos, fissile wells, high range wells, and capped areas. 


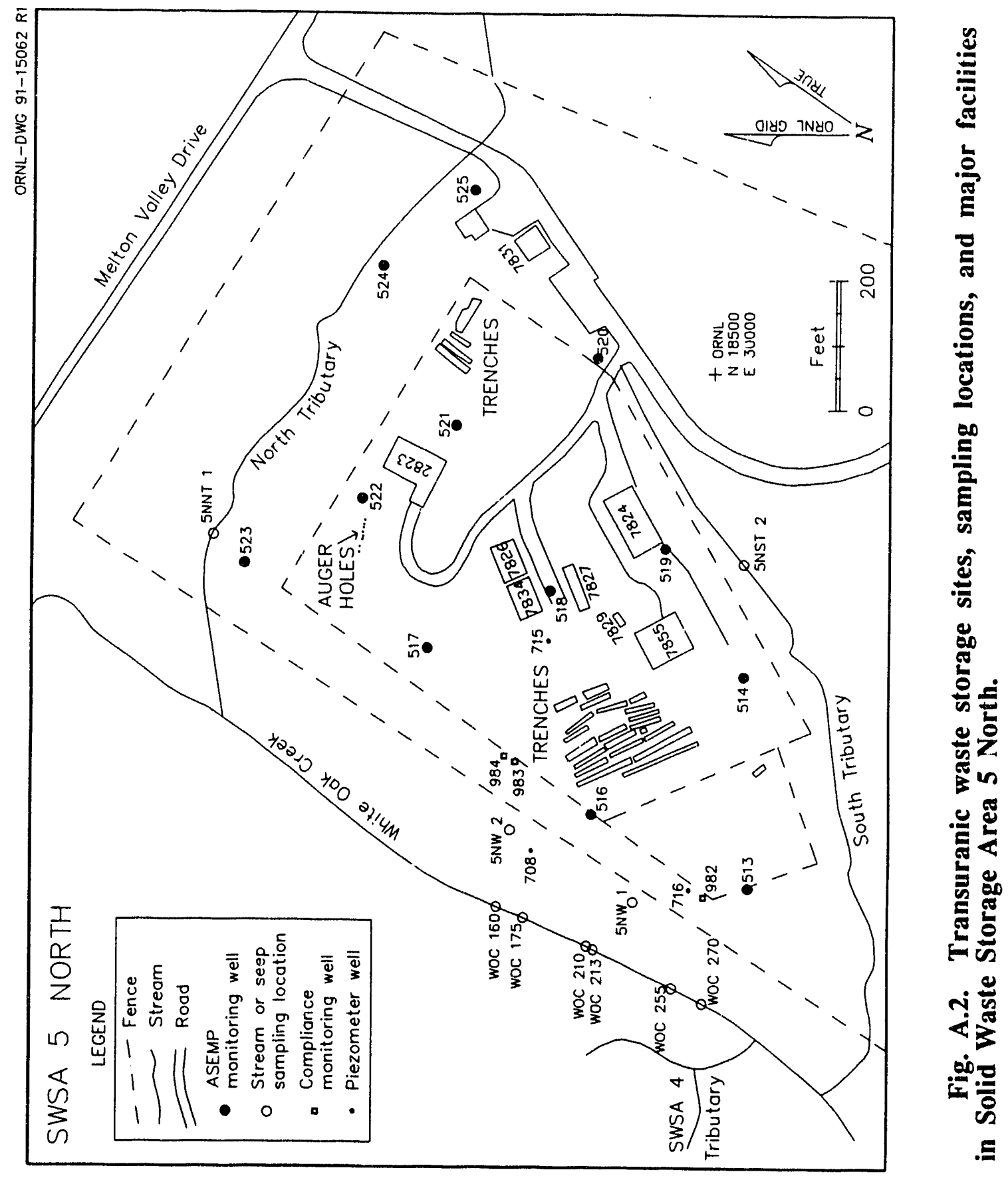




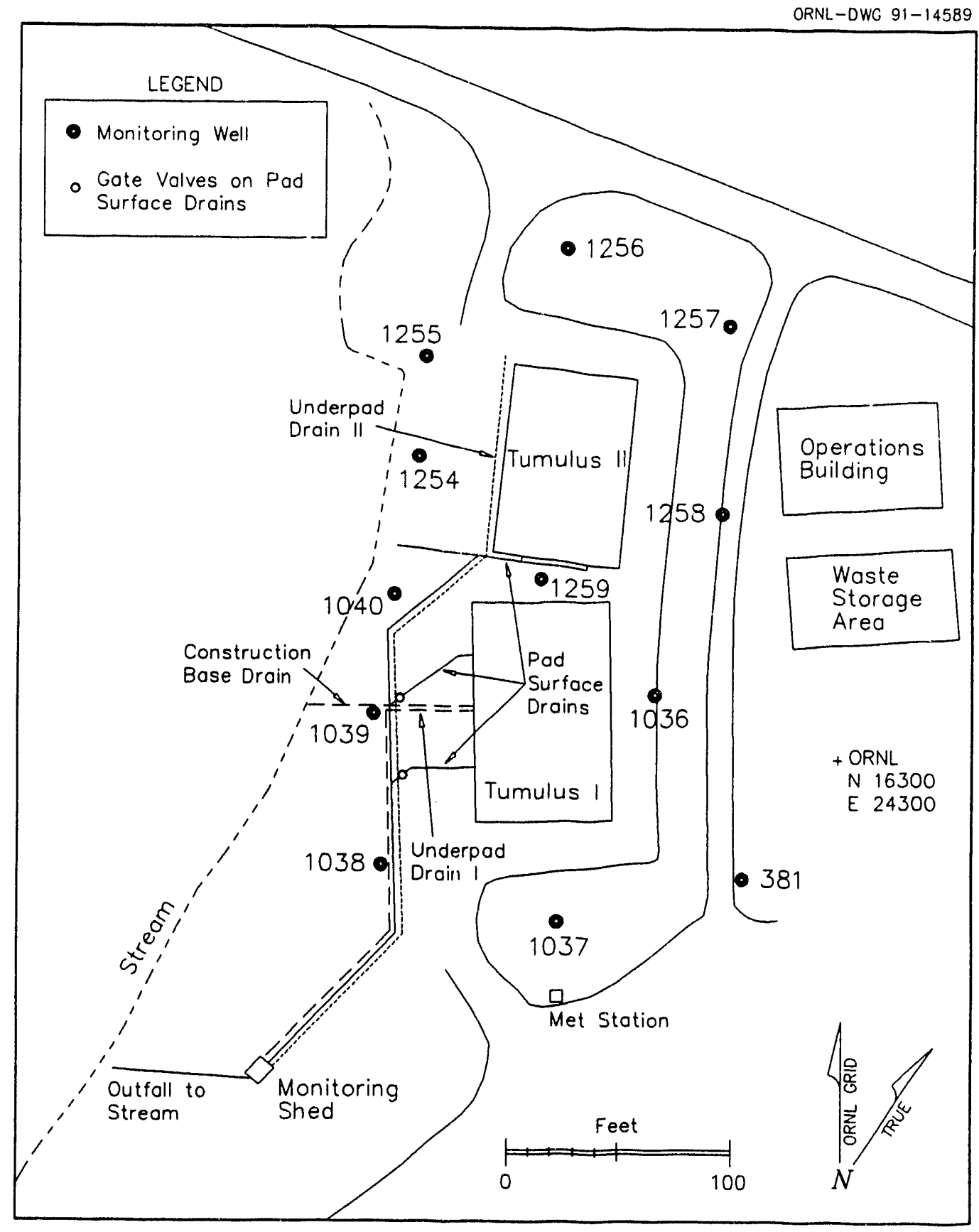

Fig. A.3. Tumulus area in Solid Waste Storage Area 6. 

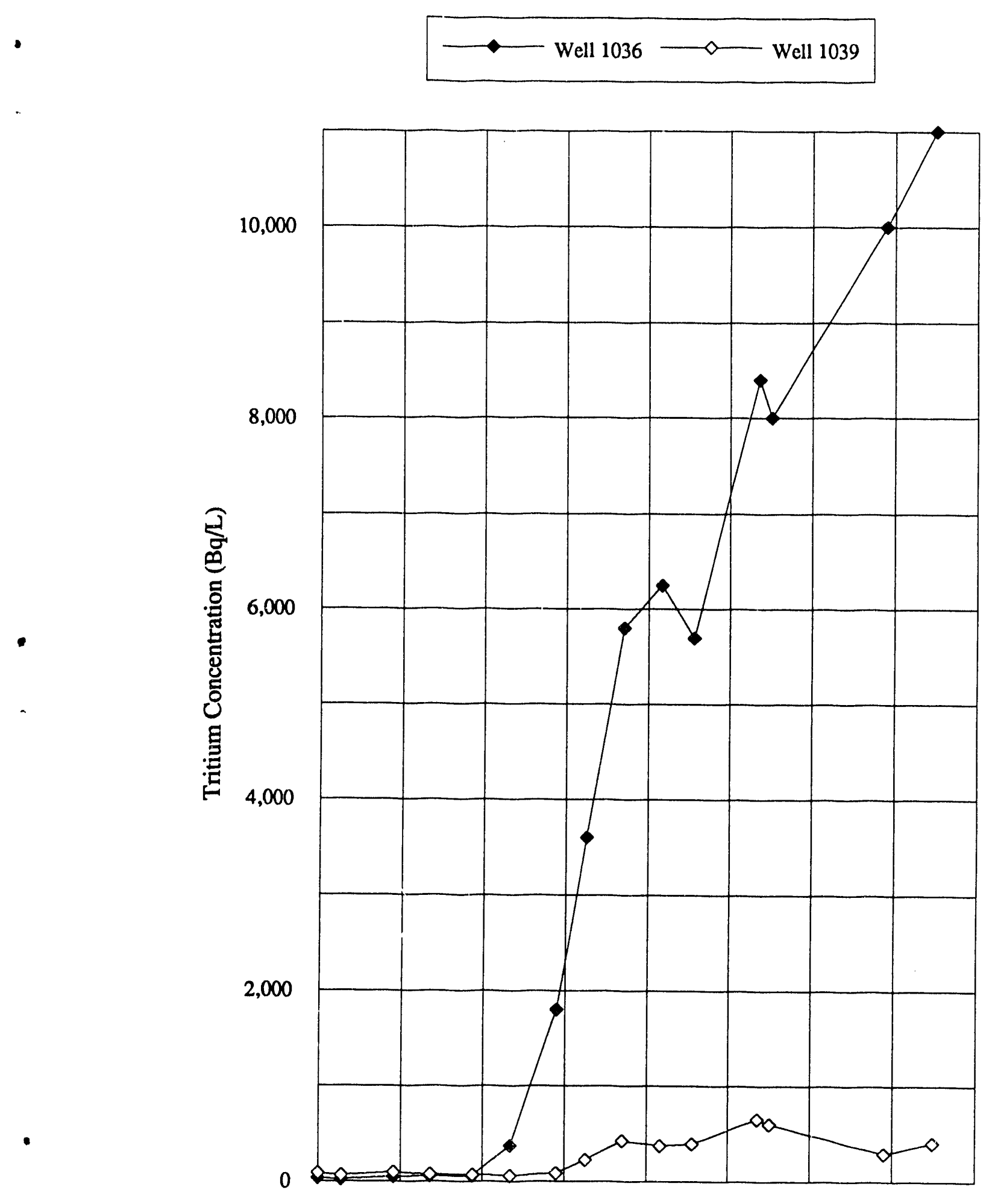

$\begin{array}{lllllllll}\text { Jun } 87 & \text { Jan } 88 & \text { Jul } 88 & \text { Feb } 89 & \text { Aug } 89 & \text { Mar } 90 & \text { Sep } 90 & \text { Apr } 91 & \text { Nov } 91\end{array}$

Fig. A.4. Tritium concentrations in wells 1036 and 1039. 
APPENDIX B: TABLES

B-1 


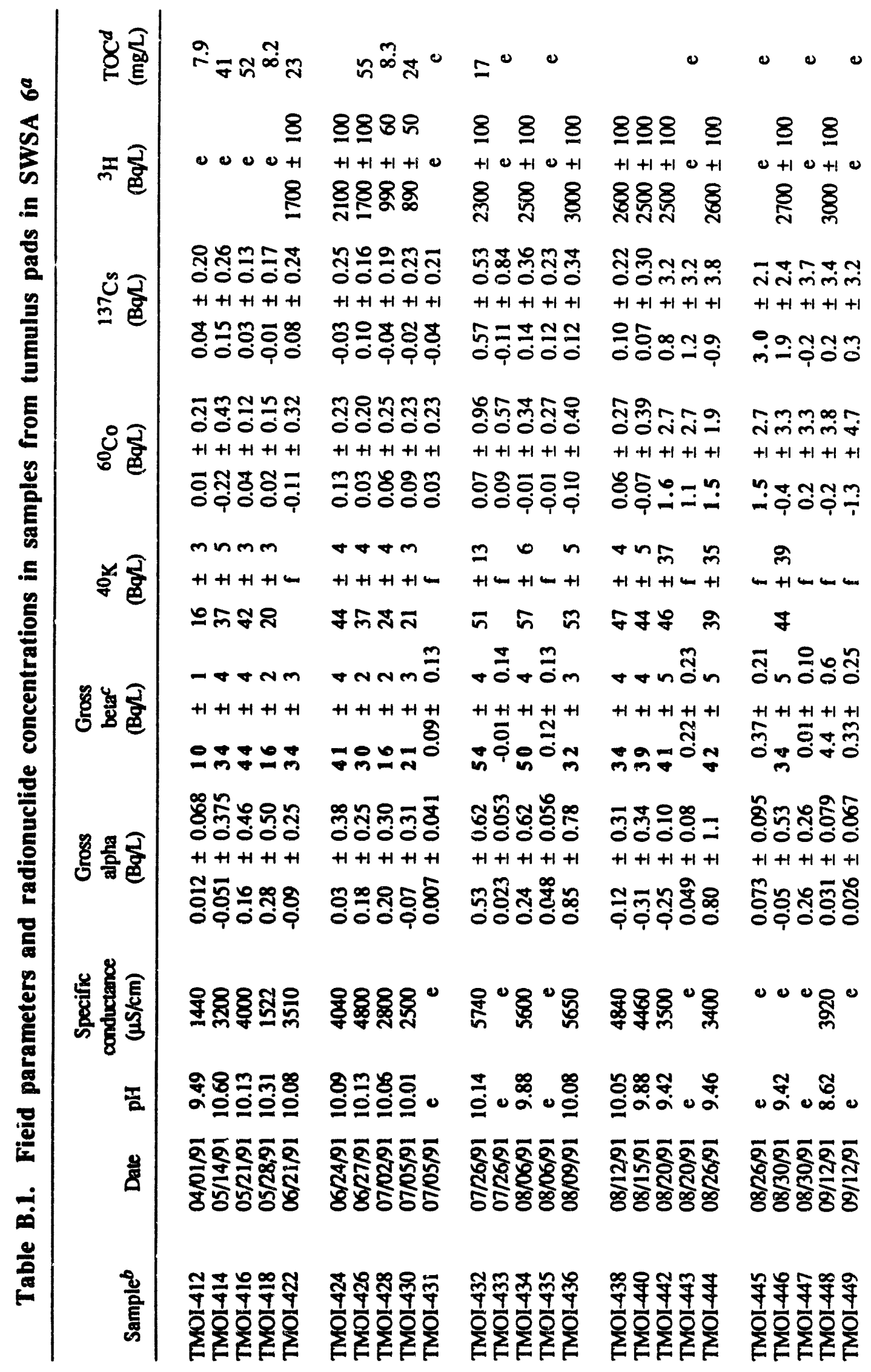

B-2 


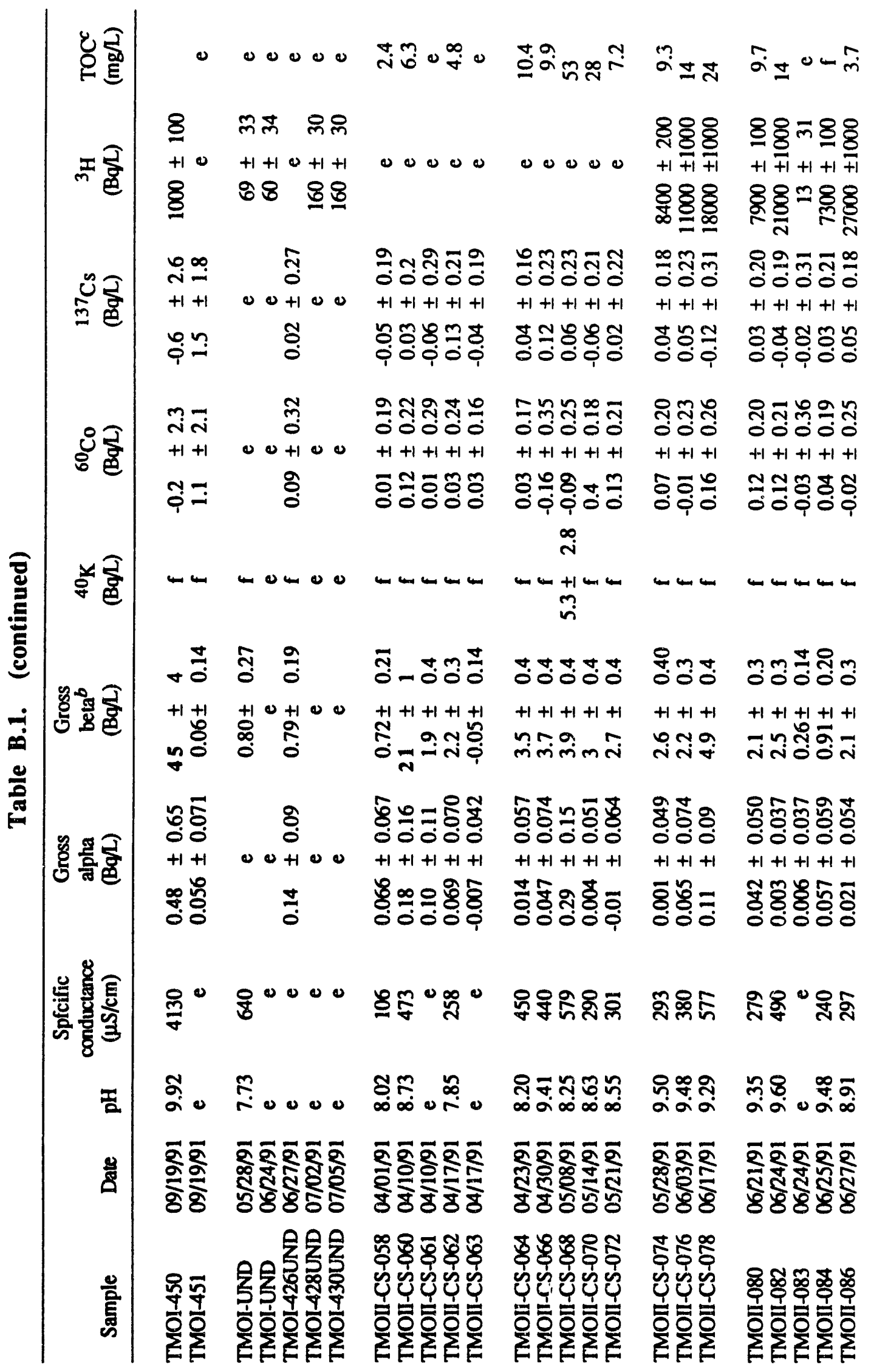




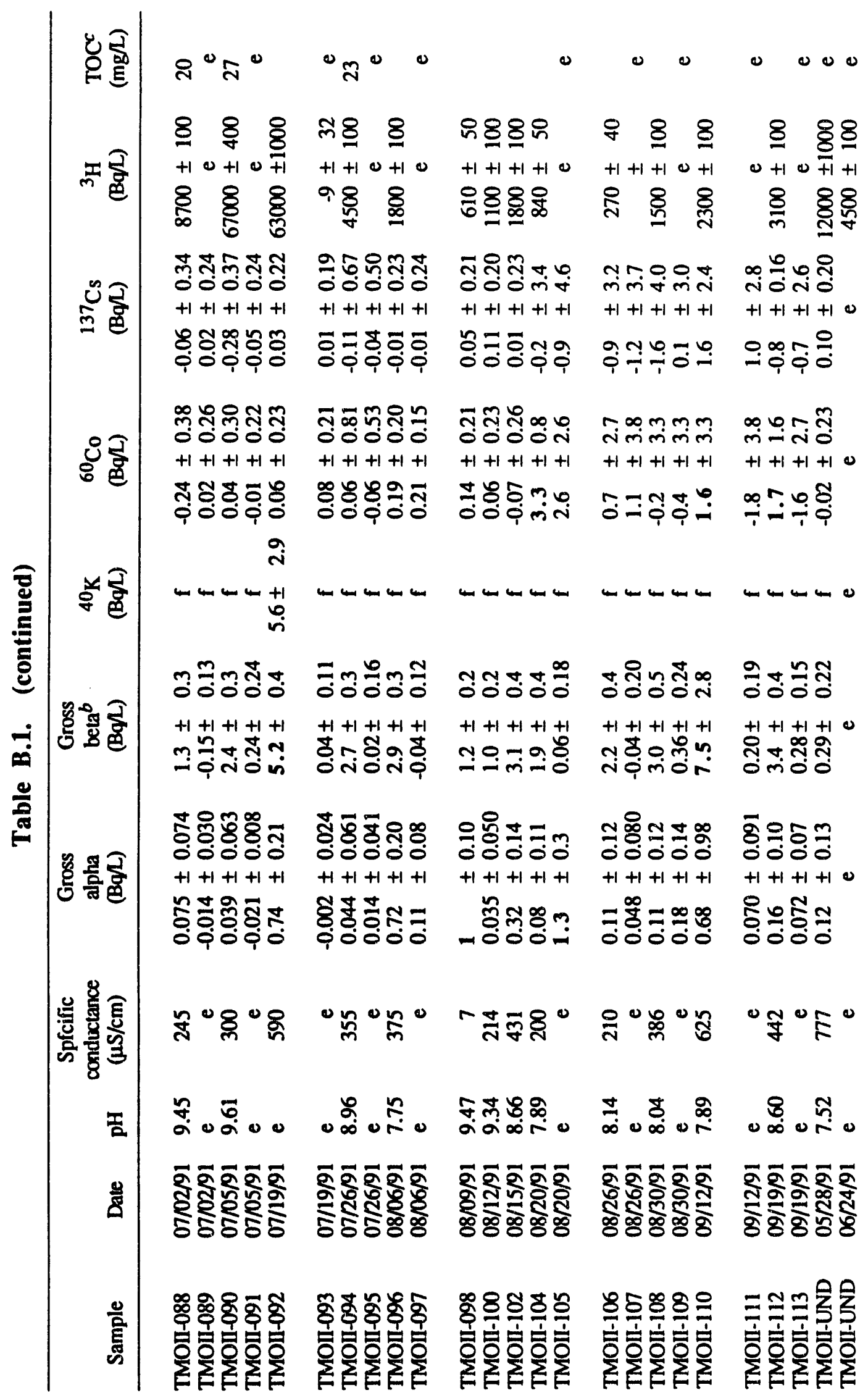




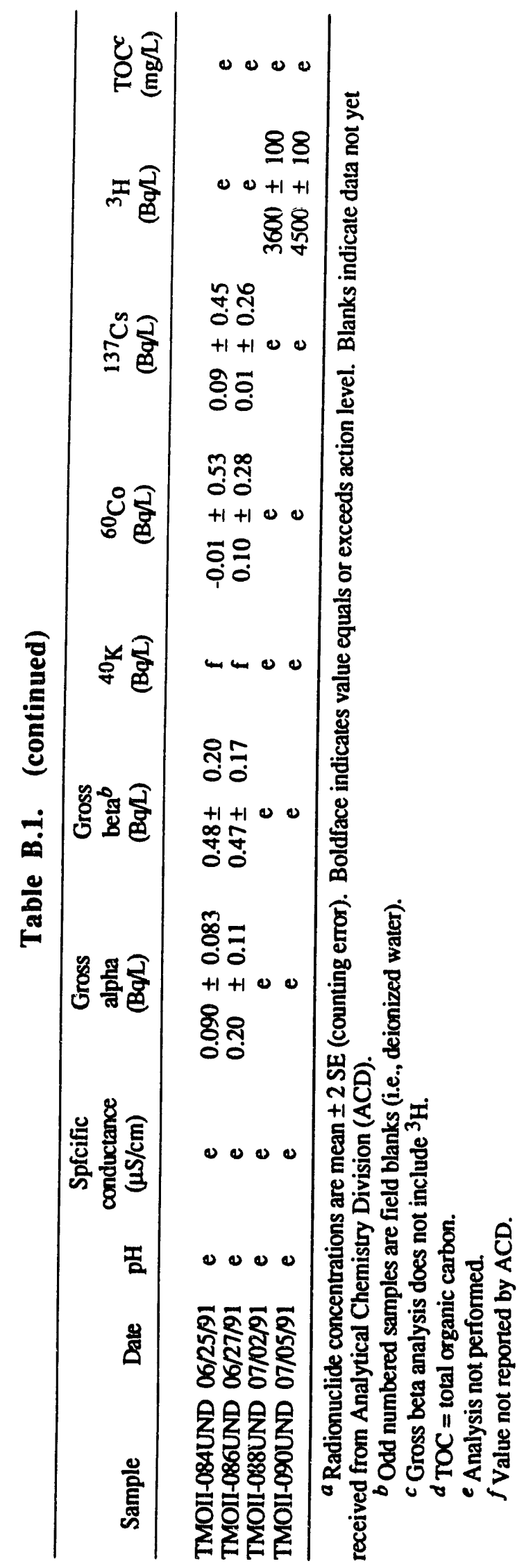

B-5 


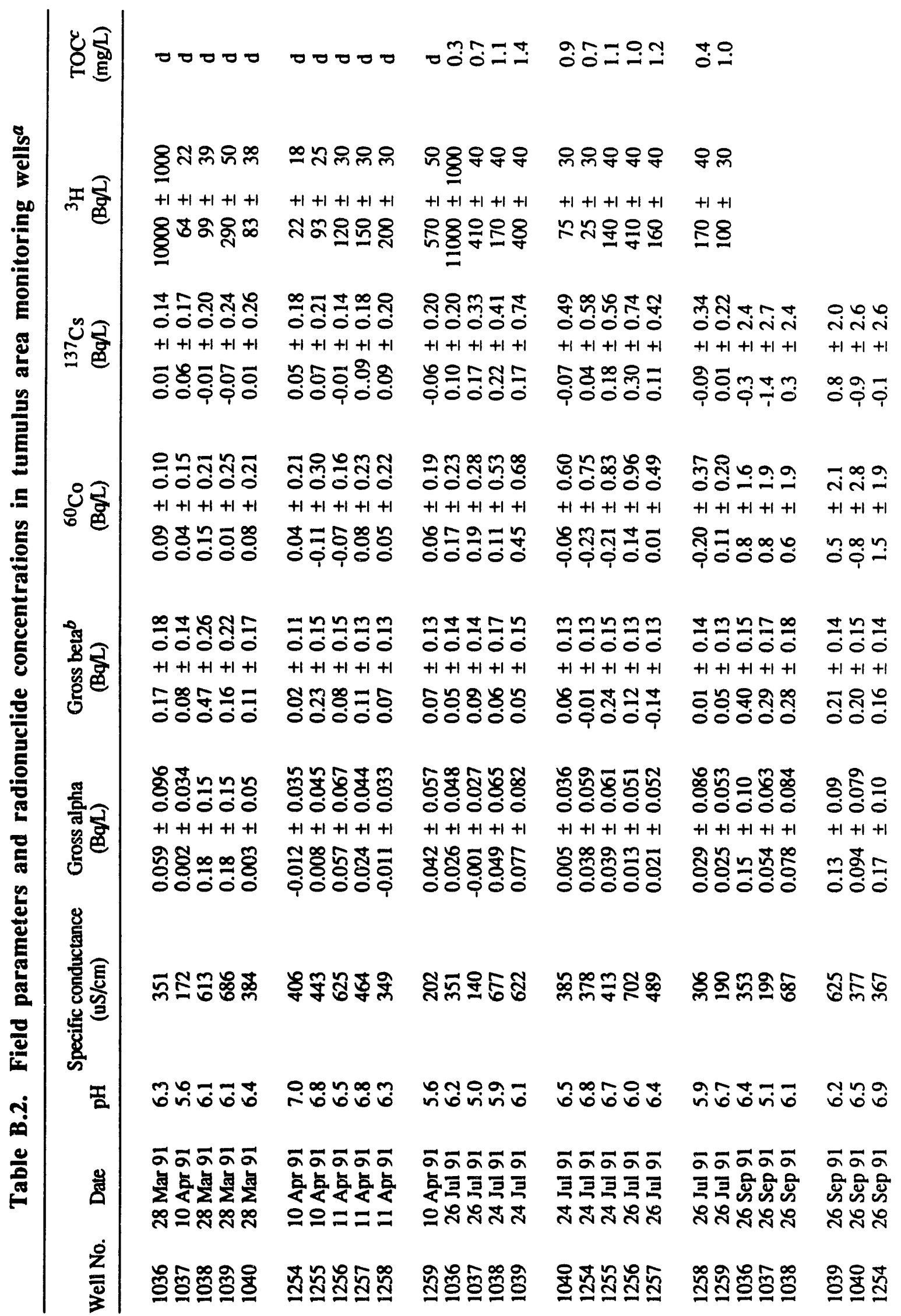




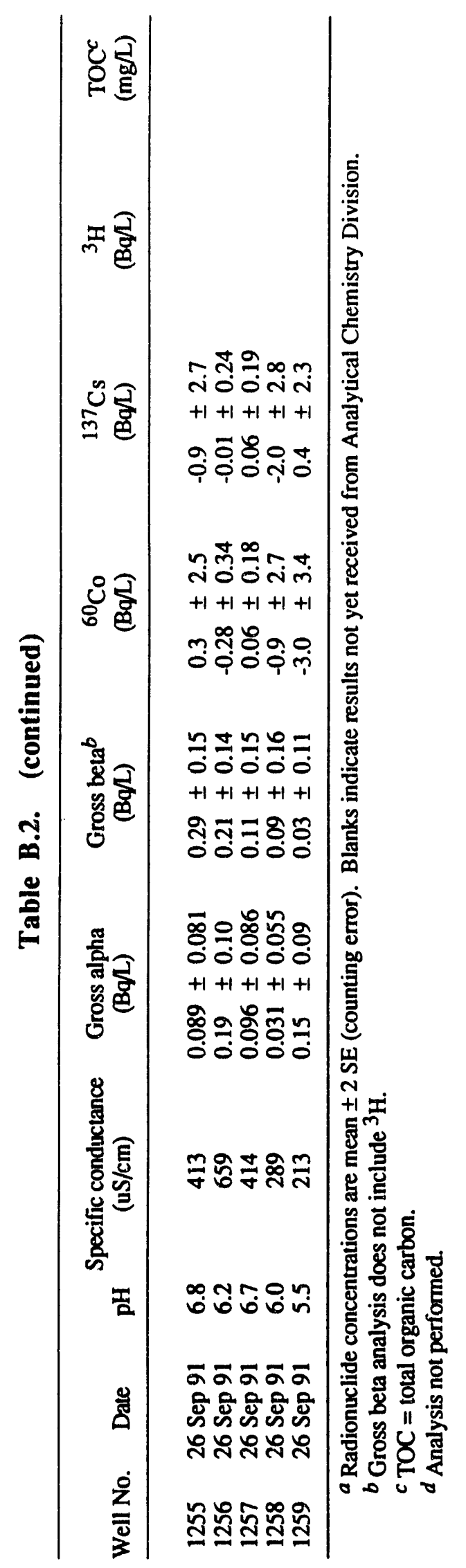

B-7 
Table B.3. Radionuclide concentrations in third quarter FY 1991 samples from intratrench wells near low-level waste $\operatorname{silos}^{a}$

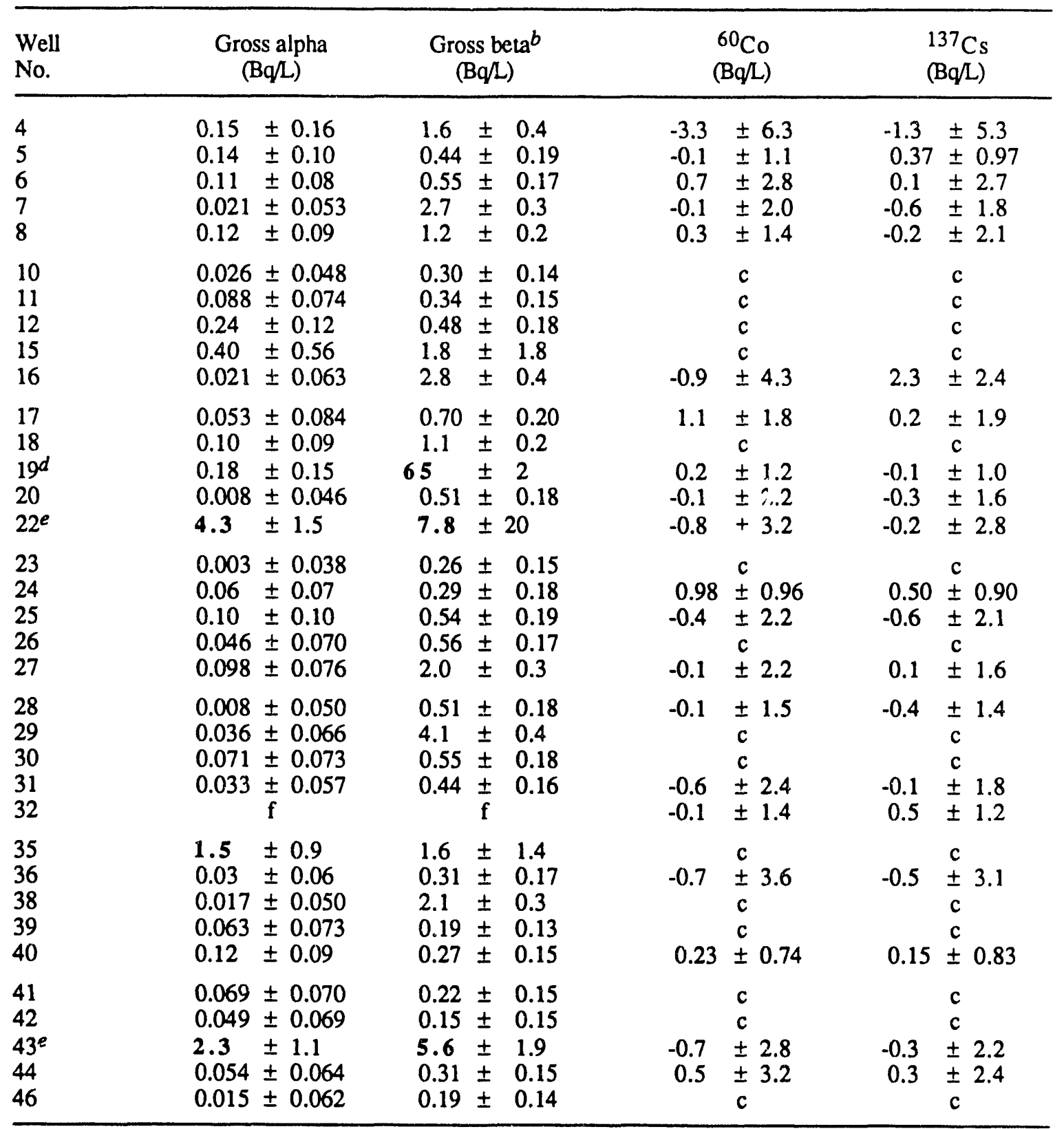

${ }^{a}$ All samples collected on 7 May 1991. Analyses performed in Analytical Chemistry Division unless otherwise indicated. Concentrations are mean $\pm 2 \mathrm{SE}$ (counting error). Boldface type indicates values exceeding action levels.

${ }^{b}$ Gross beta analysis does not include ${ }^{3} \mathrm{H}$.

${ }^{c}$ Gamma counting performed in Environmental Sciences Division (ESD). Below minimum detectable activity of $\sim 2.5 \mathrm{~Bq} / \mathrm{L}$ for ${ }^{137} \mathrm{Cs}$ and $\sim 3 \mathrm{~Bq} / \mathrm{L}$ for ${ }^{60} \mathrm{Co}$.

$d{ }^{90} \mathrm{Sr}$ concentration in this well was $38 \pm 2 \mathrm{~Bq} / \mathrm{L}$.

$e$ Gross beta and gross alpha analyses performed on $<10-\mathrm{mL}$ aliquot rather than 100 -mL aliquot because dissolved solids content was too high.

$f$ Analysis not performed. 
Table B.4. Radionuclide concentrations in third quarter FY 1991 samples from wells near high-range wells, asbestos silos, and fissile wells ${ }^{a}$

\begin{tabular}{|c|c|c|c|c|}
\hline $\begin{array}{l}\text { Well } \\
\text { No. }\end{array}$ & $\begin{array}{l}\text { Gross alpha } \\
(\mathrm{Bq} / \mathrm{L})\end{array}$ & $\begin{array}{c}\text { Gross betac } \\
(\mathrm{Bq} / \mathrm{L})\end{array}$ & $\begin{array}{l}{ }^{60} \mathrm{Co} \\
(\mathrm{B} q / \mathrm{L})\end{array}$ & $\begin{array}{l}{ }^{137} \mathrm{Cs} \\
(\mathrm{Bq} / \mathrm{L})\end{array}$ \\
\hline $\begin{array}{l}\text { AUG } 48 \\
\text { AUG } 49 \\
\text { AUG } 50 \\
\text { AUG 51 } \\
\text { AUG W536 }\end{array}$ & $\begin{array}{l}0.080 \pm 0.073 \\
0.16 \pm 0.13 \\
0.033 \pm 0.061 \\
0.00 \pm 0.05 \\
0.15 \pm 0.11\end{array}$ & $\begin{array}{c}24 \pm 1 \\
0.09 \pm 0.24 \\
0.31 \pm 0.18 \\
0.62 \pm 0.25 \\
0.63 \pm 0.21\end{array}$ & $\begin{array}{l}0.4 \pm 2.2 \\
1.2 \pm 1.4 \\
d \\
0.6 \pm 1.2 \\
0.1 \pm 3.0\end{array}$ & $\begin{array}{l}29 \pm 3 \\
-0.2 \pm 2.6 \\
\mathrm{~d} \\
0.52 \pm 0.88 \\
0.4 \pm 2.0\end{array}$ \\
\hline $\begin{array}{l}\text { AUG W540 } \\
\text { AUG W559 } \\
\text { AUG W572 }\end{array}$ & $\begin{array}{l}0.20 \pm 0.12 \\
0.037 \pm 0.075 \\
0.042 \pm 0.061\end{array}$ & $\begin{array}{l}1.3 \pm 0.2 \\
0.54 \pm 0.21 \\
0.72 \pm 0.19\end{array}$ & $\begin{array}{r}1.2 \pm 2.8 \\
1.4 \pm 0.7 \\
-0.2 \pm 1.9\end{array}$ & $\begin{array}{l}-0.5 \pm 2.8 \\
0.98 \pm 0.82 \\
0.4 \pm 1.9\end{array}$ \\
\hline $\begin{array}{l}\text { C520 } \\
\text { C595 }\end{array}$ & $\begin{array}{l}0.070 \pm 0.083 \\
1.3 \pm 0.4\end{array}$ & $\begin{array}{l}0.38 \pm 0.20 \\
1.8 \pm 0.4\end{array}$ & $\begin{array}{l}0.2 \pm 1.4 \\
0.9 \pm 1.6\end{array}$ & $\begin{array}{l}0.1 \pm 1.3 \\
0.5 \pm 1.4\end{array}$ \\
\hline $\begin{array}{l}\text { FIS } 102 \\
\text { FIS ? }\end{array}$ & $\begin{array}{l}0.036 \pm 0.062 \\
0.35 \pm 0.18\end{array}$ & $\begin{array}{l}1.1 \pm 0.2 \\
1.1 \pm 0.2\end{array}$ & $\begin{array}{l}d \\
d\end{array}$ & $\begin{array}{l}\mathrm{d} \\
\mathrm{d}\end{array}$ \\
\hline
\end{tabular}

a All samples collected 14 May 1991. Analyses performed in Analytical Chemistry Division unless otherwise noted. Concentrations are mean $\pm 2 \mathrm{SE}$. Boldface indicates value equals or exceeds action level.

${ }^{b}$ AUG = auger hole; $\mathrm{C}=$ asbestos silo; FIS = fissile well.

$c$ Gross beta analysis does not include ${ }^{3} \mathrm{H}$.

$d$ Gamma counting performed by Environmental Sciences Division. Below minimum detectable activity of $\sim 2.5 \mathrm{~Bq} / \mathrm{L}$ for ${ }^{137} \mathrm{Cs}$ and $\sim 3 \mathrm{~Bq} / \mathrm{L}$ for ${ }^{60} \mathrm{Co}$. 
Table B.5. Radionuclide concentrations in fourth quarter FY 1991 samples from intratrench wells near low-level waste $\operatorname{silos}^{a}$

\begin{tabular}{|c|c|c|c|c|c|}
\hline $\begin{array}{l}\text { Well } \\
\text { No. }\end{array}$ & Date & $\begin{array}{c}\text { Gross alpha } \\
(\mathrm{Bq} / \mathrm{L})\end{array}$ & $\begin{array}{c}\text { Gross beta }{ }^{b} \\
(\mathrm{~Bq} / \mathrm{L})\end{array}$ & $\begin{array}{l}{ }^{60} \mathrm{Co} \\
(\mathrm{Bq} / \mathrm{L})\end{array}$ & $\begin{array}{l}{ }^{137} \mathrm{Cs} \\
(\mathrm{Bq} / \mathrm{L})\end{array}$ \\
\hline $\begin{array}{l}5 \\
6 \\
7 \\
8 \\
10\end{array}$ & $\begin{array}{l}13 \text { Sep } 91 \\
13 \text { Sep } 91 \\
13 \text { Sep } 91 \\
13 \text { Sep } 91 \\
13 \text { Sep } 91\end{array}$ & $\begin{array}{l}0.023 \pm 0.096 \\
0.075 \pm 0.076 \\
0.14 \pm 0.20 \\
-0.010 \pm 0.074 \\
0.05 \pm 0.11\end{array}$ & $\begin{array}{l}0.30 \pm 0.28 \\
0.34 \pm 0.15 \\
0.21 \pm 0.44 \\
0.61 \pm 0.36 \\
0.22 \pm 0.27\end{array}$ & $\begin{array}{r}1.4 \pm 1.6 \\
0.8 \pm 3.7 \\
-0.3 \pm 3.5 \\
1.3 \pm 1.3 \\
-3.3 \pm 5.7\end{array}$ & $\begin{array}{l}1.9 \pm 3.9 \\
1.3 \pm 3.4 \\
-3 \pm 10 \\
1.4 \pm 1.3 \\
0.2 \pm 2.7\end{array}$ \\
\hline $\begin{array}{l}11 \\
12 \\
15 \\
17 \\
20\end{array}$ & $\begin{array}{l}13 \operatorname{Sep} 91 \\
13 \operatorname{Sep} 91 \\
13 \text { Sep } 91 \\
13 \operatorname{Sep} 91 \\
13 \operatorname{Sep} 91\end{array}$ & $\begin{array}{c}0.11 \pm 0.12 \\
0.09 \pm 0.12 \\
0.08 \pm 0.12 \\
0.06 \pm 0.15 \\
-0.015 \pm 0.090\end{array}$ & $\begin{array}{l}0.21 \pm 0.29 \\
0.13 \pm 0.25 \\
0.34 \pm 0.29 \\
0.33 \pm 0.41 \\
0.18 \pm 0.27\end{array}$ & $\begin{array}{r}0.6 \pm 3.0 \\
3.0 \pm 1.5 \\
0.8 \pm 2.5 \\
1.5 \pm 3.2 \\
-1.3 \pm 4.8\end{array}$ & $\begin{array}{r}0.9 \pm 2.0 \\
-0.4 \pm 4.2 \\
0.2 \pm 3.2 \\
-1.6 \pm 4.4 \\
-0.4 \pm 4.6\end{array}$ \\
\hline $\begin{array}{l}22 \\
23 \\
24 \\
25 \\
26\end{array}$ & $\begin{array}{l}13 \text { Sep } 91 \\
13 \text { Sep } 91 \\
13 \text { Sep } 91 \\
13 \text { Sep } 91 \\
13 \text { Sep } 91\end{array}$ & $\begin{array}{l}0.07 \pm 0.12 \\
0.014 \pm 0.086 \\
-0.029 \pm 0.085 \\
0.09 \pm 0.12 \\
0.11 \pm 0.14\end{array}$ & $\begin{array}{l}0.39 \pm 0.33 \\
0.04 \pm 0.21 \\
0.17 \pm 0.29 \\
0.44 \pm 0.35 \\
0.06 \pm 0.28\end{array}$ & $\begin{array}{r}-0.1 \pm 2.5 \\
-1.0 \pm 4.8 \\
1.9 \pm 3.0 \\
-0.8 \pm 5.0 \\
-0.3 \pm 1.0\end{array}$ & $\begin{array}{l}-1.6 \pm 3.5 \\
-0.2 \pm 3.2 \\
-1.7 \pm 4.4 \\
0.6 \pm 3.0 \\
0.39 \pm 0.98\end{array}$ \\
\hline $\begin{array}{l}27 \\
28 \\
30 \\
31 \\
32\end{array}$ & $\begin{array}{l}13 \text { Sep } 91 \\
13 \text { Sep } 91 \\
13 \text { Sep } 91 \\
13 \text { Sep } 91 \\
13 \text { Sep } 91\end{array}$ & $\begin{array}{l}2.5 \pm 1.8 \\
-0.31 \pm 0.48 \\
0.9 \pm 1.2 \\
1.8 \pm 1.5 \\
0.016 \pm 0.098\end{array}$ & $\begin{array}{l}1.9 \pm 2.9 \\
4.5 \pm 2.8 \\
0.1 \pm 2.4 \\
2.8 \pm 3.1 \\
0.60 \pm 0.33\end{array}$ & $\begin{array}{r}-0.3 \pm 4.8 \\
1.4 \pm 1.3 \\
-0.1 \pm 2.1 \\
3.6 \pm 1.5 \\
1.6 \pm 2.9\end{array}$ & $\begin{array}{r}-0.1 \pm 4.9 \\
-0.3 \pm 3.0 \\
-0.1 \pm 2.6 \\
0.2 \pm 4.2 \\
0.4 \pm 3.4\end{array}$ \\
\hline $\begin{array}{l}34 \\
35 \\
36 \\
38 \\
39\end{array}$ & $\begin{array}{l}13 \text { Sep } 91 \\
13 \text { Sep } 91 \\
13 \text { Sep } 91 \\
16 \text { Sep } 91 \\
16 \text { Sep } 91\end{array}$ & $\begin{array}{l}-0.094 \pm 0.031 \\
0.14 \pm 0.14 \\
0.10 \pm 0.12 \\
0.036 \pm 0.091 \\
0.16 \pm 0.14\end{array}$ & $\begin{array}{l}3.8 \pm 0.7 \\
0.68 \pm 0.31 \\
0.25 \pm 0.28 \\
2.20 \pm 0.40 \\
0.17 \pm 0.26\end{array}$ & $\begin{array}{l}1.4 \pm 2.1 \\
3.9 \pm 1.5 \\
0.3 \pm 2.7 \\
0.5 \pm 1.5 \\
0.40 \pm 0.99\end{array}$ & $\begin{array}{r}-0.8 \pm 4.9 \\
0.6 \pm 4.2 \\
-0.4 \pm 2.8 \\
0.6 \pm 1.4 \\
-0.1 \pm 1.4\end{array}$ \\
\hline $\begin{array}{l}40 \\
41 \\
42 \\
43 \\
44 \\
46\end{array}$ & $\begin{array}{l}16 \text { Sep } 91 \\
16 \text { Sep } 91 \\
16 \text { Sep } 91 \\
16 \text { Sep } 91 \\
16 \text { Sep } 91 \\
16 \text { Sep } 91\end{array}$ & $\begin{array}{l}0.11 \pm 0.13 \\
0.06 \pm 0.11 \\
0.26 \pm 0.18 \\
0.13 \pm 0.15 \\
0.12 \pm 0.20 \\
0.04 \pm 0.07\end{array}$ & $\begin{array}{l}-0.08 \pm 0.27 \\
0.27 \pm 0.26 \\
0.64 \pm 0.32 \\
0.50 \pm 0.32 \\
1.3 \pm 0.5 \\
0.22 \pm 0.17\end{array}$ & $\begin{array}{r}1.2 \pm 0.8 \\
0.6 \pm 3.2 \\
0.2 \pm 3.0 \\
-0.7 \pm 3.7 \\
0.9 \pm 3.0 \\
0.3 \pm 3.0\end{array}$ & $\begin{array}{r}1.2 \pm 1.4 \\
1.3 \pm 1.5 \\
-2.7 \pm 5.7 \\
2.2 \pm 2.9 \\
-0.5 \pm 2.6 \\
0.5 \pm 2.4\end{array}$ \\
\hline
\end{tabular}

a All analyses performed by Analytical Chemistry Division. Concentrations are mean $\pm 2 \mathrm{SE}$. Boldface indicates value equals or exceeds action level.

${ }^{b}$ Gross beta analysis does not include ${ }^{3} \mathrm{H}$. 
Table B.6. Radionuclide concentrations in fourth quarter FY 1991 samples from wells near high-range wells, asbestos silos, and fissile wells ${ }^{a}$

\begin{tabular}{lllll}
\hline $\begin{array}{c}\text { Well } \\
\text { No } b\end{array}$ & $\begin{array}{c}\text { Gross alpha } \\
(\mathrm{Bq} / \mathrm{L})\end{array}$ & $\begin{array}{c}\text { Gross beta } \\
(\mathrm{Bq} / \mathrm{L})\end{array}$ & $\begin{array}{c}60 \mathrm{Co} \\
(\mathrm{Bq} / \mathrm{L})\end{array}$ & \multicolumn{1}{c}{$\begin{array}{c}137 \mathrm{Cs} \\
(\mathrm{Bq} / \mathrm{L})\end{array}$} \\
\hline AUU 48 & $0.42 \pm 0.31$ & $2.1 \pm 0.6$ & $1.4 \pm 1.3$ & $2.0 \pm 1.7$ \\
AUU 49 & $0.22 \pm 0.22$ & $0.64 \pm 0.43$ & $0.3 \pm 3.0$ & $0.7 \pm 2.4$ \\
AUG 50 & $0.36 \pm 0.30$ & $1.1 \pm 0.5$ & $2.0 \pm 1.5$ & $1.2 \pm 2.6$ \\
AUG W559 & $0.14 \pm 0.21$ & $0.55 \pm 0.44$ & $\mathbf{3 . 3} \pm 3.4$ & $-0.1 \pm 3.2$ \\
AUG W572 & $0.19 \pm 0.21$ & $1.0 \pm 0.6$ & $1.0 \pm 5.9$ & $-0.6 \pm 4.6$ \\
C520 & $0.27 \pm 0.28$ & $0.91 \pm 0.58$ & $-2.3 \pm 7.0$ & $-1.9 \pm 5.4$ \\
C595 & $0.47 \pm 0.39$ & $1.2 \pm 0.6$ & $-0.9 \pm 6.3$ & $-0.3 \pm 4.6$ \\
FIS 102 & $0.52 \pm 0.34$ & $2.0 \pm 0.6$ & $0.8 \pm 1.3$ & $-0.1 \pm 3.2$ \\
FIS? & $0.20 \pm 0.22$ & $0.90 \pm 0.46$ & $\mathbf{1 . 6 \pm 2 . 1}$ & $0.2 \pm 2.4$ \\
\hline
\end{tabular}

${ }^{a}$ All samples collected 18 September 1991. Analyses performed in Analytical Chemistry Division. Concentrations are mean $\pm 2 \mathrm{SE}$. Boldface indicates value equals or exceeds action level.

$b$ AUG $=$ auger hole; $\mathrm{C}=$ asbestos silo; FIS $=$ fissile well.

$c$ Gross beta analysis does not include ${ }^{3} \mathrm{H}$. 
Table B.7. Radionuclide concentrations in samples from tank 1 at the Hillcut Disposal Test Facility in SWSA $6^{a}$

\begin{tabular}{ccccc}
\hline Date & Gross alpha & Gross beta $b$ & ${ }^{60} \mathrm{Co}$ & ${ }^{137 \mathrm{Cs}}$ \\
\hline 2 April 91 & $0.029 \pm 0.076$ & $0.84 \pm 0.3$ & $0.18 \pm 0.36$ & $0.11 \pm 0.38$ \\
18 July 91 & $0.28 \pm 0.13$ & $1.8 \pm 0.3$ & $1.4 \pm 1.4$ & $0.2 \pm 2.1$ \\
\hline
\end{tabular}

${ }^{a}$ All analyses performed by Analytical Chemistry Division. Results are mean $\pm 2 \mathrm{SE}$ (counting error).

$b$ Gross beta analysis does not include ${ }^{3} \mathrm{H}$. 


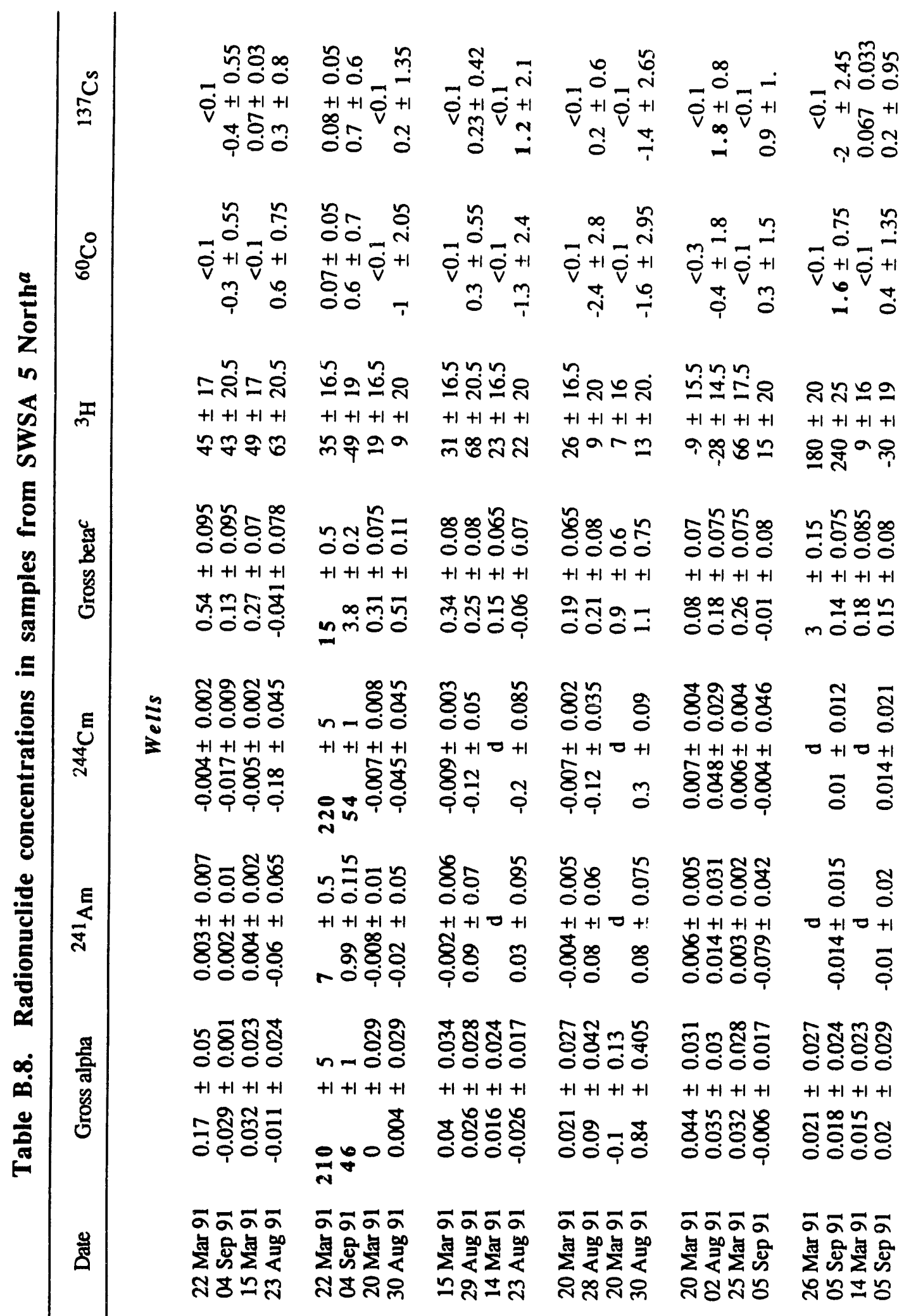

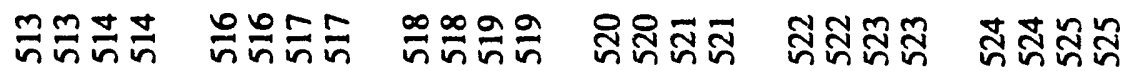




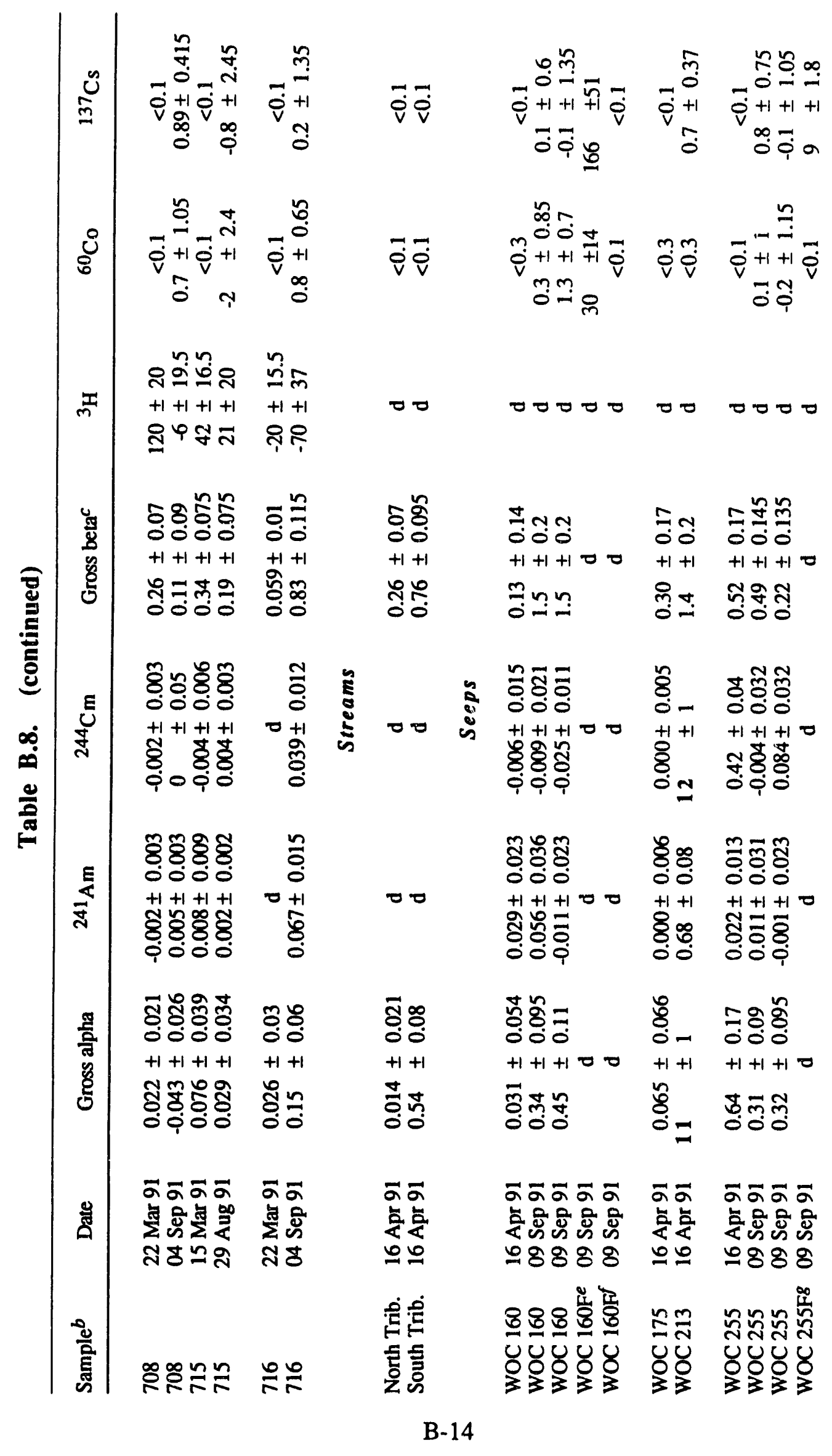




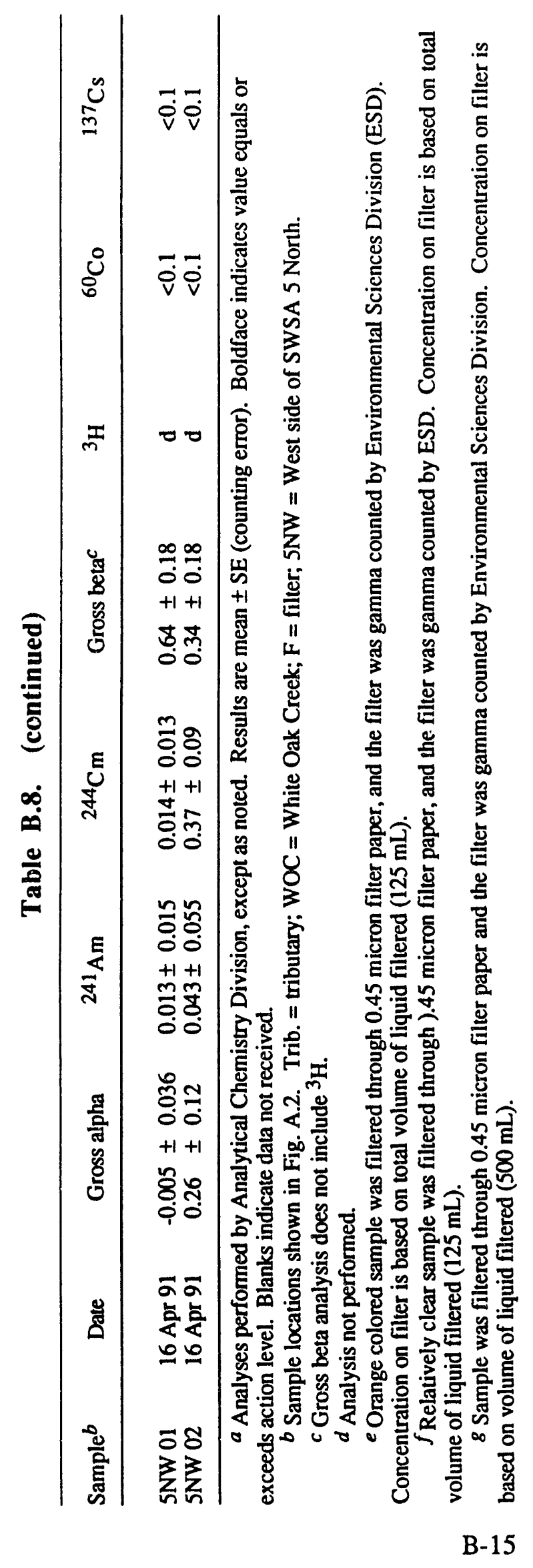




\section{INTERNAL DISTRIRUTION}

1. H. L. Adair

2-6. T. L. Ashwood

7. F. P. Baxter

8. D. M. Borders

9. H. L. Boston

10. J. B. Cannon

11. R. B. Clapp

12. T. O. Early

13. C. J. Ford

14. C. W. Francis

15. D. F. Hall

16-18. D. S. Hicks

19. S. G. Hildebrand

20. D. D. Huff

21. C. A. Manrod

22. B. C. McClelland

23. W'. M. McMaster
24. L. E. McNeese

25-27. C. M. Morrissey

28. J. B. Murphy

29. C. E. Nix

30. T. F. Scanlan

31. S. H. Stow

32. J. R. Trabalka

33. S. D. Van Hoesen

34. L. D. Voorhees

35. J. A. Watts

36. C. Whitmire, Jr.

37. Central Research Library

38-47. ESD Library

48-49. Laboratory Records Dept.

50. Laboratory Records, ORNL-RC

51. ORNL Patent Section

52. ORNL Y-12 Technical Library

\section{EXTERNAL DISTRIBUTION}

53. J. F. Franklin, Bloedel Professor of Ecosystem Analysis, College of Forest Resources, University of Washington, Anderson Hall (AR-10), Seattle, WA 98195

54. R. C. Harriss, Institute for the Study of Earth, Oceans, and Space, Science and Engineering Research Building, University of New Hampshire, Durham, NH 03824

55. G. Y. Jordy, Director, Office of Program Analysis, Office of Energy Research ER-30, G-226, U.S. Department of Energy, Washington, DC 20545

56. R. H. Olsen, Professor, Microbiology and Immunology Department, University of Michigan, Medical Sciences II, \#5605, 1301 East Catherine Street, Ann Arbor, MI 48109-0620

57. A. Patrinos, Director, Environmental Sciences Division, Office of Health and Environmental Research, ER-74, U. S Department of Energy, Washington, DC 20585

58. F. J. Wobber, Environmental Sciences Division, Office of Health and Environmental Research, Office of Energy Research, ER-74, Department of Energy, Washington, DC 20585

59. Office of Assistant Manager for Energy Research and Development, U.S. Depariment of Energy Oak Ridge Field Office, P.O. Box 2001, Oak Ridge, TN 37831-8600

60-69. Office of Scientific and Technical Information, P.O. Box 62, Oak Ridge, TN 37831 

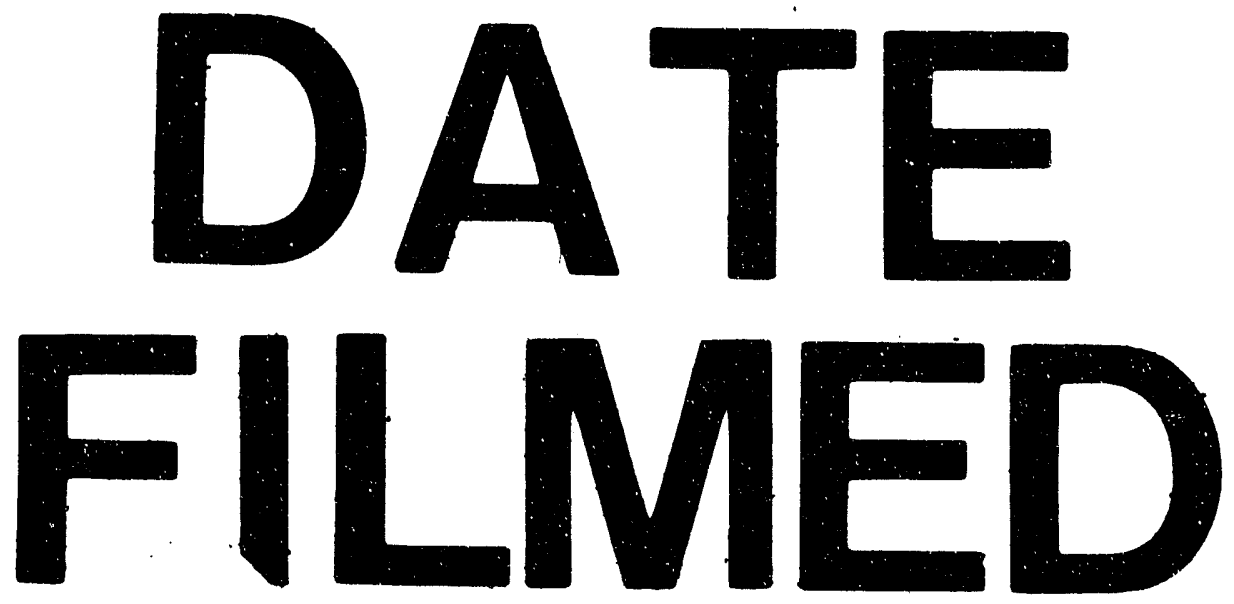

01108193 
. 